\section{Pacific Northwest}

National Laboratory

Operated by Battelle for the

U.S. Department of Energy

\title{
The Soils and Groundwater - EM-20 SET Roadmap Quality Assurance Project Plan
}

N. J. Fix

February 2008

Prepared for the U.S. Department of Energy under Contract DE-AC05-76RL01830 


\title{
DISCLAIMER
}

This report was prepared as an account of work sponsored by an agency of the United States Government. Neither the United States Government nor any agency thereof, nor Battelle Memorial Institute, nor any of their employees, makes any warranty, express or implied, or assumes any legal liability or responsibility for the accuracy, completeness, or usefulness of any information, apparatus, product, or process disclosed, or represents that its use would not infringe privately owned rights. Reference herein to any specific commercial product, process, or service by trade name, trademark, manufacturer, or otherwise does not necessarily constitute or imply its endorsement, recommendation, or favoring by the United States Government or any agency thereof, or Battelle Memorial Institute. The views and opinions of authors expressed herein do not necessarily state or reflect those of the United States Government or any agency thereof.

\author{
PACIFIC NORTHWEST NATIONAL LABORATORY \\ operated by \\ BATTELLE \\ for the \\ UNITED STATES DEPARTMENT OF ENERGY \\ under Contract DE-AC05-76RL01830
}

Printed in the United States of America

Available to DOE and DOE contractors from the Office of Scientific and Technical Information, P.O. Box 62, Oak Ridge, TN 37831; prices available from (615) 576-8401.

Available to the public from the National Technical Information Service, U.S. Department of Commerce, 5285 Port Royal Rd., Springfield, VA 22161 
PNNL-17323

\section{The Soils and Groundwater - EM-20 S\&T Roadmap Quality Assurance Project Plan}

N.J. Fix

February 2008

Prepared for

the U.S. Department of Energy

under Contract DE-AC05-76RL01830

Pacific Northwest National Laboratory

Richland, Washington 99352 



\title{
The Soils and Groundwater - EM-20 S\&T Roadmap Quality Assurance Project Plan
}

\author{
Project \# 53910 \\ Prepared by \\ Pacific Northwest National Laboratory \\ Richland, Washington 99352
}

Issue Date: February 2008

\begin{abstract}
Approval:
D.D. Dauble, Product Line Manager Environmental Science \& Technology
\end{abstract}

T.L. Stewart, Project Manager Energy and Environment Division

\section{Concurrence:}

N.J. Fix, Project Quality Engineer Quality Assurance Services
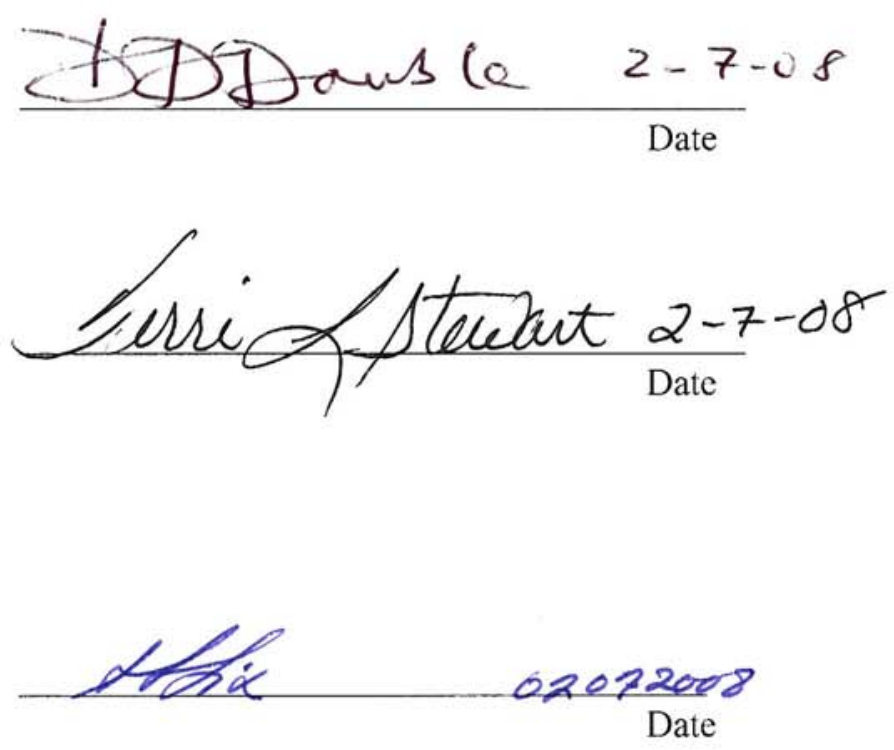



\section{Summary}

The Soils and Groundwater - EM-20 Science and Technology Roadmap Project (herein referred to as the EM-20 Roadmap Project) is a U.S. Department of Energy, Office of Environmental Management-funded initiative designed to develop new methods, strategies and technology for characterizing, modeling, remediating, and monitoring soils and groundwater contaminated with metals, radionuclides, and chlorinated organics.

The work scope is managed under a master project (project number 53910) with a number of associated funded projects (referred to as “child projects”) over the term of the contract. Each child project has a separate statement of work, with funding and costs tracked individually for reporting purposes.

This Quality Assurance Project Plan provides the quality assurance requirements and processes that will be followed by EM-20 Roadmap Project staff. This plan is based on the requirements in the EPA Requirements for Quality Assurance Project Plans (QA-R-5) (EPA/240/B-01/003 ${ }^{1}$ ) in accordance with the Hanford Federal Facility Agreement and Consent Order (commonly referred to as the Tri-Party Agreement [Ecology et al. 1989²]); DOE O 414.1C, Quality Assurance ${ }^{3}$; and 10 Code of Federal Regulations 830, Subpart A, “Quality Assurance Requirements." ${ }^{4}$ The Price-Anderson Amendments Act $t^{5}$ also applies to this project.

\footnotetext{
${ }^{1}$ EPA/240/B-01/003. 2001. EPA Requirements for Quality Assurance Project Plans (QA/R-5). U.S. Environmental Protection Agency, Washington, D.C.

2 Ecology - Washington State Department of Ecology, U.S. Environmental Protection Agency, and U.S. Department of Energy. 1989, as amended. Hanford Federal Facility Agreement and Consent Order. Document No. 89-10, Olympia, Washington.

${ }^{3}$ DOE Order 414.1C. 2005. Quality Assurance. U.S. Department of Energy, Washington, D.C.

410 CFR 830, Subpart A, “Quality Assurance Requirements.” U.S. Code of Federal Regulations.

${ }^{5}$ Price-Anderson Amendments Act. Energy Policy Act of 2005. Title VI-Nuclear Matters, Subtitle A-PriceAnderson Act Amendments, Section 601 et. seq. Public Law 109-58, as amended. 42 USC 15801 et seq.
} 



\section{Abbreviations and Acronyms}

ATS

CAWSRP

CERCLA

CFR

CMP

DOE

DQO

EM

EPA

ESL QAP

$\mathrm{FH}$

FY

HASQARD

ICN

LOI

LRB

M\&TE

MDA

MDL

MOA

OJT

PAAA

PDF

PI

PMP

PNNL

PNSO

QA

QAP
Assessment Tracking System

Conducting Analytical Work in Support of Regulatory Programs

Comprehensive Environmental Response, Compensation, and

Liability Act

Code of Federal Regulations

Configuration Management Plan

U.S. Department of Energy

Data Quality Objectives

DOE Office of Environmental Management

U.S. Environmental Protection Agency

Environmental Sciences Laboratory Quality Assurance Plan

Fluor Hanford, Inc.

fiscal year

Hanford Analytical Services Quality Assurance Requirements

Documents

Interim Chance Notice

letter of instruction

laboratory record book

measuring and test equipment

minimum detectable activity

method detection limits

Memorandum of Agreement

on-the-job-training

Price-Anderson Amendments Act

portable document format

Principal Investigator

Project Management Plan

Pacific Northwest National Laboratory

Pacific Northwest Site Office

quality assurance

Quality Assurance Plan 


$\begin{array}{ll}\text { QAPjP } & \text { Quality Assurance Project Plan } \\ \text { QC } & \text { quality control } \\ \text { RCRA } & \text { Resource Conservation and Recovery Act of 1976 } \\ \text { RDR } & \text { Review Document Record } \\ \text { RIDS } & \text { Records Inventory and Disposition Schedule } \\ \text { RPG } & \text { requirements, procedures and guidelines } \\ \text { RTDI } & \text { Records Transfer/ Data Input Form } \\ \text { SBMS } & \text { Standards-Based Management System } \\ \text { SDD } & \text { Software Design Description } \\ \text { SOW } & \text { statements of work } \\ \text { SRR } & \text { Software Requirements Review } \\ \text { SRS } & \text { Software Requirements Specifications } \\ \text { TRIM } & \text { Total Records Information Management } \\ \text { V\&VPR } & \text { Verification and Validation Plan Review } \\ \text { VPP } & \text { Verification and Validation Plan } \\ \text { VVR } & \text { Verification and Validation Report } \\ \text { WBR } & \text { workstation backup and restore } \\ \text { WBS } & \text { Work Breakdown Structure }\end{array}$




\section{Contents}

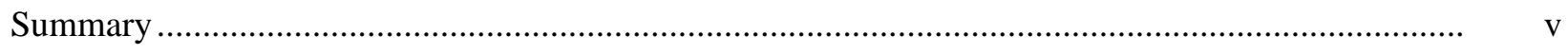

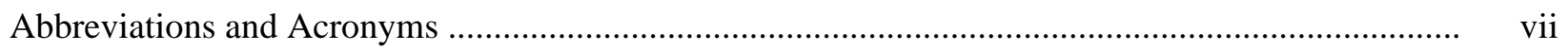

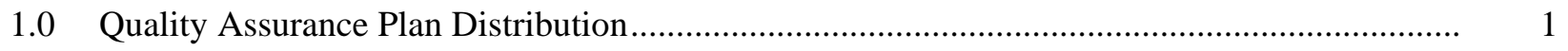

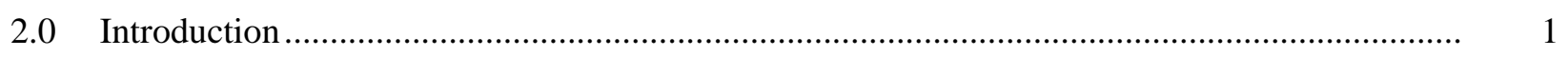

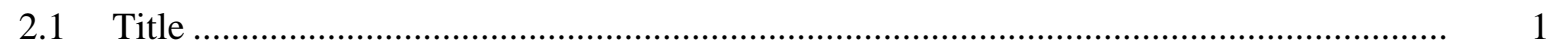

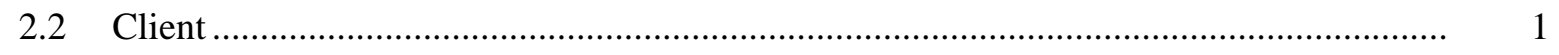

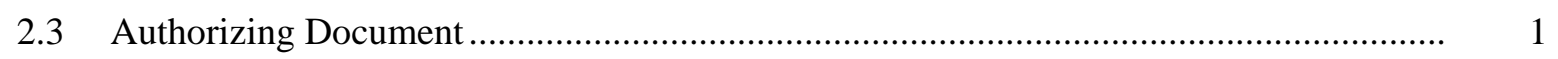

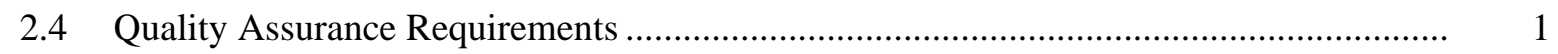

2.5 Special Requirements or Specifications ........................................................................ 2

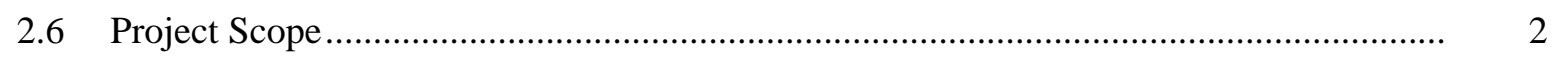

2.6.1 Develop Advanced Fate and Transport Models - Conceptual and Numerical Model Development for High-Risk Contaminants and Sites (WBS 2.2.1) ........ 3

2.6.2 Develop Approaches for Integrating Life-Cycle Monitoring Data into Site Models (WBS 2.2.2) ....................................................................................... 3

2.6.3 Develop Advanced Remediation Methods for Metals and Radionuclide Scientific and Technical Basis for in-situ treatment systems for Metals and Radionuclides (WBS 2.3.1.1) ........................................................................... 3

2.6.4 Demonstrate Methods to Reduce Transport Rate of Chlorinated Organics through Deep Vadose Zone (WBS 2.3.2.2) ........................................................ 4

2.6.5 Columbia River Projects Follow-On Activities (WBS 2.5.0) .............................. 4

2.7 Change Control (Scope, Schedule, Budget) ................................................................. 5

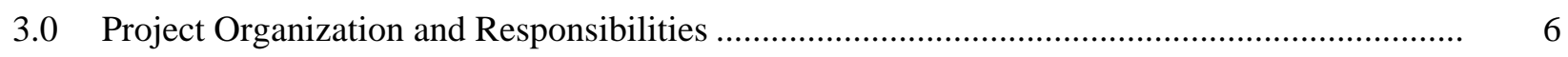

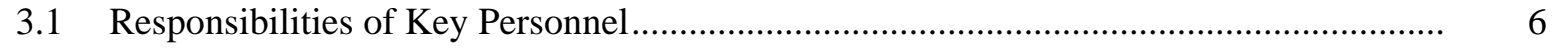

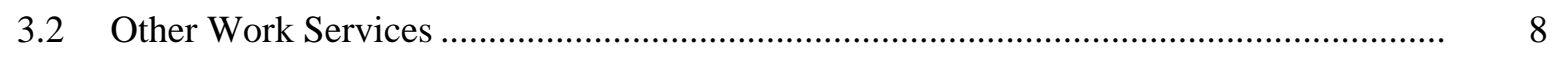

3.2.1 Analytical Services ............................................................................... 8

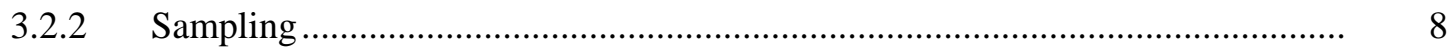

3.2.3 Well Drilling, Sampling, and Construction Services........................................ 9

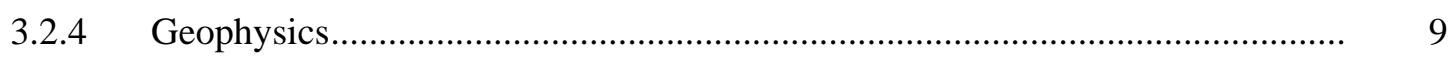

3.2.5 Field Measurements................................................................................... 9

3.2.6 Other Services.............................................................................................. 9

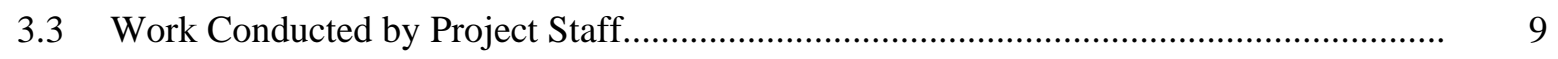

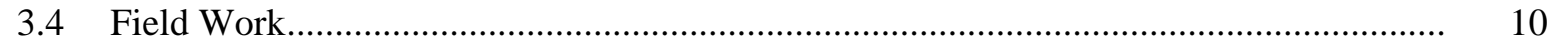

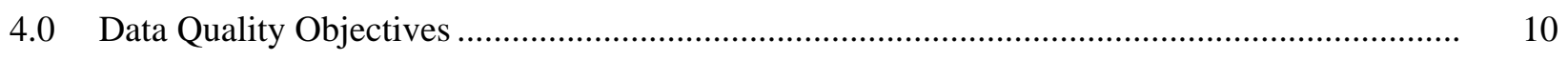

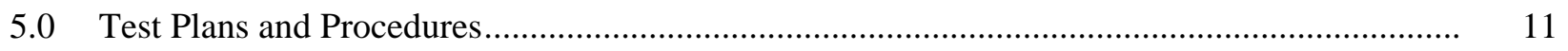

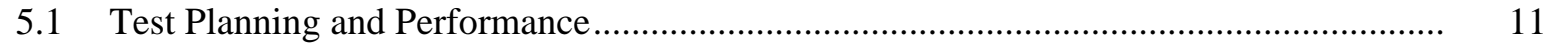

5.1.1 Developing the Test Plan ......................................................................... 11

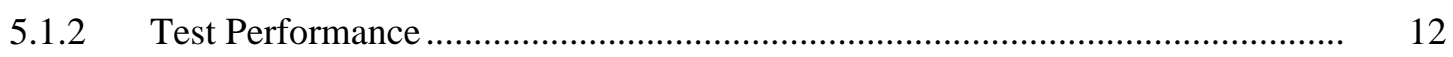

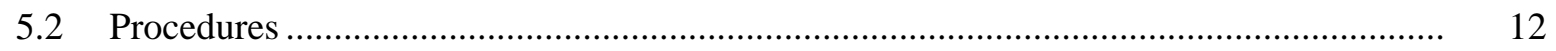




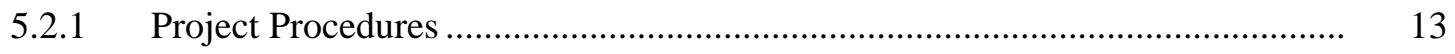

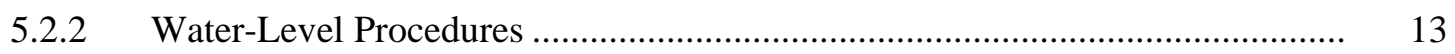

5.2.3 Analytical Procedures ................................................................................. 13

5.2.4 Calibration Procedures................................................................................ 14

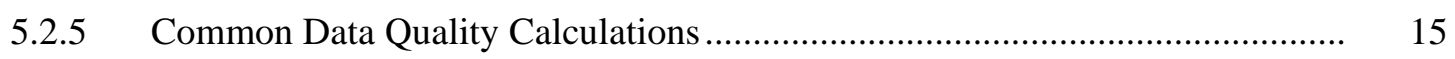

5.2.6 Well Drilling and Construction Procedures....................................................... 15

5.2.7 Water and Sediment Sample Collection Procedures ......................................... 15

5.2.8 Receiving and Handling Samples .................................................................. 16

5.2.9 Sediment Physical Analysis Procedures .......................................................... 16

5.2.10 Sediment Core Analysis Procedures............................................................... 16

5.2.11 Geophysical Logging Procedures .............................................................. 16

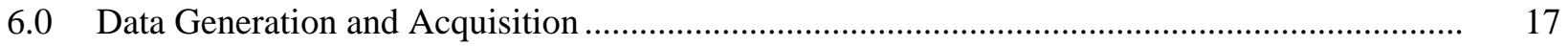

6.1 Experimental Design (Sampling Process Design)........................................................ 17

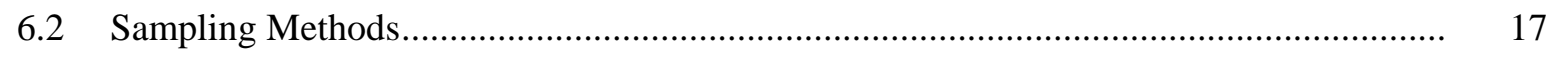

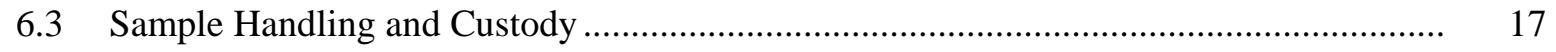

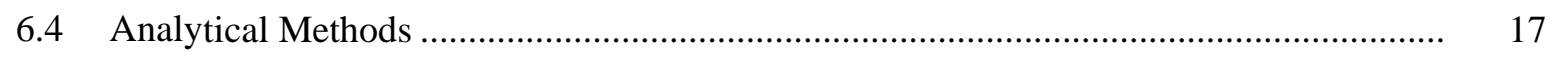

7.0 Data Reduction, Verification, and Reporting..................................................................... 18

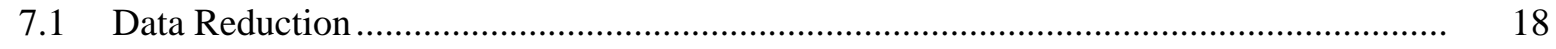

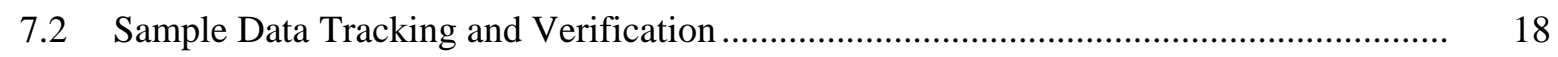

7.3 Sample Data and Tracking for Sediment and Other Media Samples .............................. 18

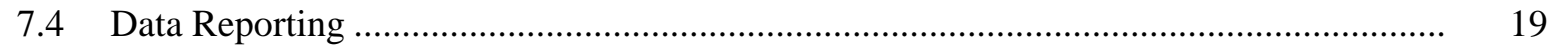

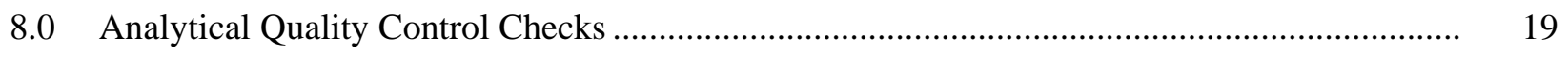

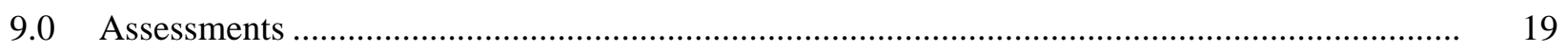

9.1 Assessment Planning and Documentation................................................................. 20

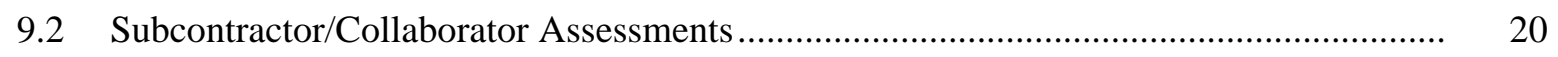

10.0 Preventive Equipment Maintenance...................................................................................... 23

11.0 Specific Routine Procedures Used to Assess Data Precision, Accuracy, and Completeness ..... 23

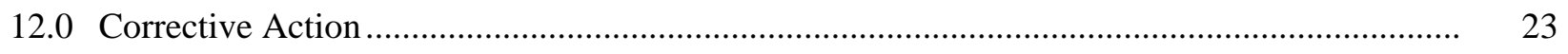

12.1 Project Corrective Actions Resulting from Assessments ............................................... 23

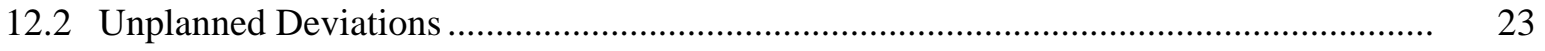

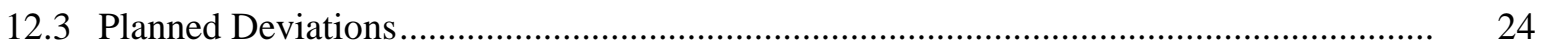

12.4 Measuring and Test Equipment Calibration Discrepancies …....................................... 24

13.0 Quality Assurance Reports to Management......................................................................... 24

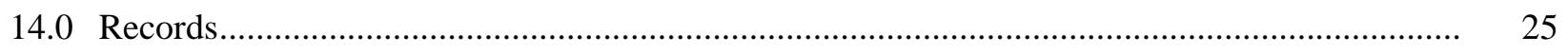

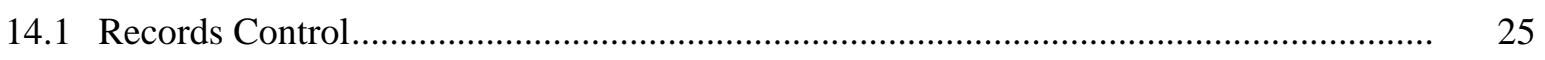

14.2 Records Transfer to Storage …............................................................................... 25

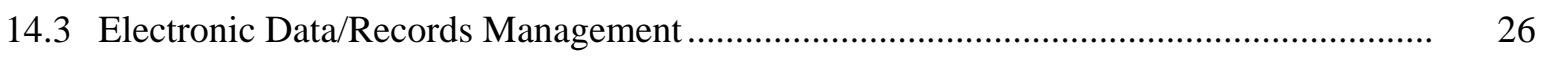

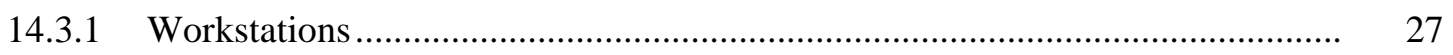

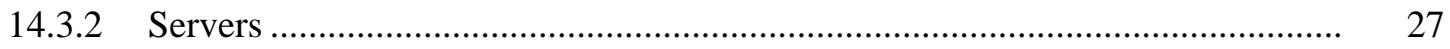




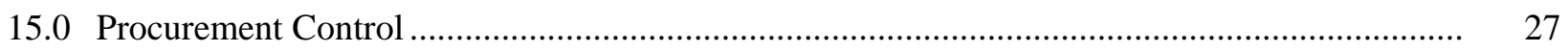

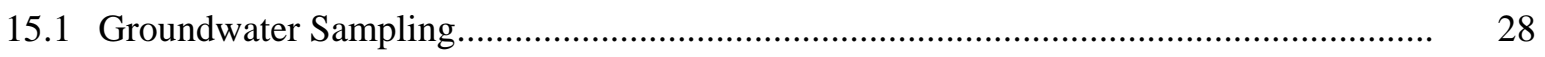

15.2 Groundwater and/or Sediment Analytical Measurements.............................................. 28

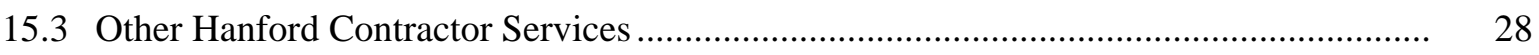

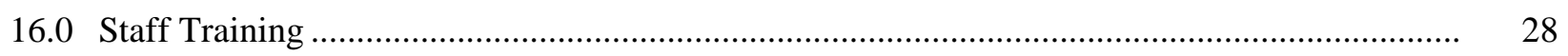

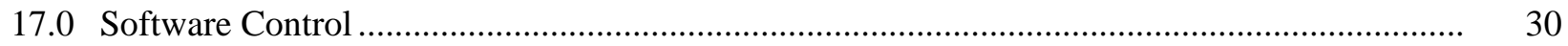

17.1 Software and Software Applications ...................................................................... 30

17.1.1 Minimum Documentation Requirements....................................................... 31

17.1.2 Software Requirements Specification.............................................................. 31

17.1.3 Software Design Description..................................................................... 31

17.1.4 Verification and Validation Plan ................................................................. 32

17.1.5 Verification and Validation Report...................................................................... 33

17.1.6 User Documentation ................................................................................ 33

17.1.7 Configuration Management Plan ................................................................ 33

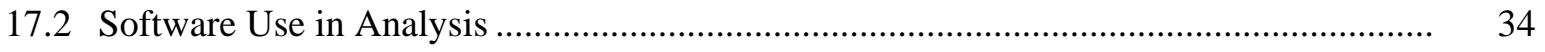

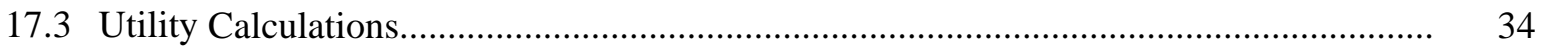

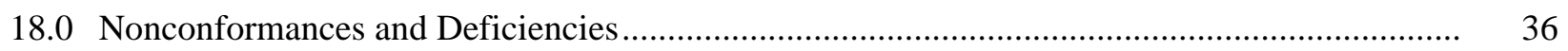

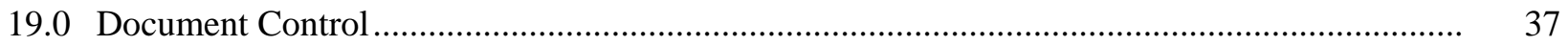

19.1 Project Quality Assurance Plan Control................................................................... 37

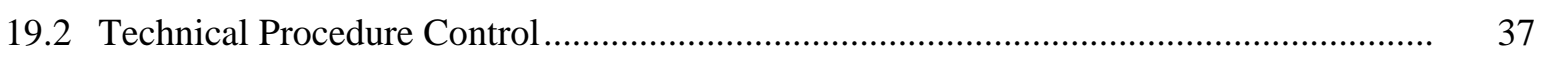

19.3 Administrative Procedure/Instruction Preparation and Control ...................................... 37

19.4 Test Plans and Other Work Documents ...................................................................... 40

19.5 Field Notebooks and Laboratory Record Books .......................................................... 40

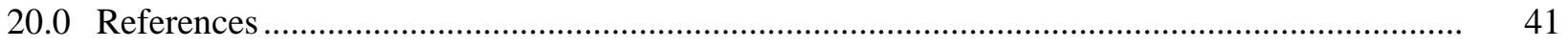

Appendix A - EM-20 Roadmap Project Quality Control Plan..................................................... A.1

Appendix B - Experimental and Modeling Procedures for the EM-20 Roadmap Project .................. B. B.1

\section{Figures}

3.1 Organizational Relationships for the Soil and Groundwater - EM-20 S\&T Roadmap Project .. 7

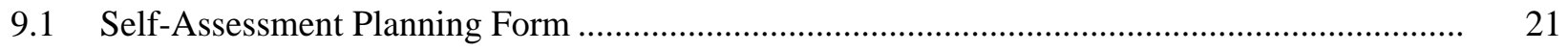

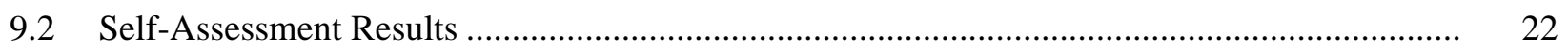

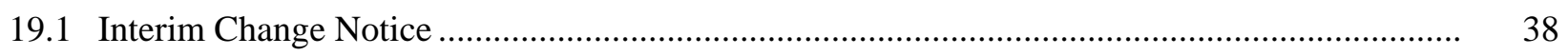

\section{Tables}

17.1 Software Risk Management Examples 



\subsection{Quality Assurance Plan Distribution}

Pacific Northwest National Laboratory (PNNL) document control will distribute this Quality Assurance (QA) Project Plan (QAPjP) internally to PNNL and to the U.S. Department of Energy (DOE), Office of Environmental Management (EM); DOE Pacific Northwest Site Office; and DOE Richland Operations Office, as requested. The Project Manager will determine the final PNNL and external distribution list. Also, the QAPjP will be published in accordance with the PNNL Standards Based Management System (SBMS) subject area, "Publishing Scientific and Technical Information”

(PNNL 2007d).

\subsection{Introduction}

\subsection{Title}

The title of this project is as follows: Soils and Groundwater - EM-20 S\&T Roadmap Project (herein after referred to as the EM-20 Roadmap Project).

\subsection{Client}

The client is DOE EM in Washington, D.C.

\subsection{Authorizing Document}

The project is a DOE-EM funded initiative designed to develop new methods, strategies and technology for characterizing, modeling, remediating, and monitoring soils and groundwater contaminated with metals, radionuclides, and chlorinated organics. The work scope will be managed under a master project (project number 53910) with a number of funded associated projects (referred to as "child projects") over the term of the contract. Each child project has a statement of work, with funding and costs tracked individually for reporting purposes.

The contract for this master project is 1830 Other DOE Sites (IWO, MPO, IPAC) with multiple funding sources. The budget and reporting number is EY4049110. The master project is scheduled to be funded from fiscal year (FY) 2007 through FY 2013 for a total value of \$32,700,000.00.

\subsection{Quality Assurance Requirements}

Contaminated areas at the Hanford Site that must be remediated are subject to the Hanford Federal Facility Agreement and Consent Order (Tri-Party Agreement; Ecology et al. 1989) and the associated Tri-Party Agreement Action Plan under the Comprehensive Environmental Response, Compensation, and Liability Act (CERCLA). The signatory parties to the Tri-Party Agreement (DOE, the U.S. Environmental Protection Agency [EPA], and the Washington State Department of Ecology [Ecology]) have agreed to programmatic requirements associated with Hanford Site remediation. As stated, the project is funded by DOE-EM as a research effort, but with the objective that results may be used to 
support future site remediation strategies and activities, including those at the Hanford Site and other DOE-EM sites that are subject to regulatory-driven milestones and negotiations. Therefore, project staff has made the determination that the project will comply with the requirements in the EPA Requirements for Quality Assurance Project Plans (QA/R-5) (EPA/240/B-01/003) in accordance with the Tri-Party Agreement (Ecology et al. 1989).

The QAPjP is also based on the QA requirements of DOE Order 414.1C, Quality Assurance, and 10 Code of Federal Regulations (CFR) 830, Subpart A, Quality Assurance Requirements, as described in the PNNL SBMS. The project is subject to the Price Anderson Amendments Act (PAAA) as defined in the PNNL PAAA Program and implemented through the SBMS subject area, "Price-Anderson Amendments Act” (PNNL 2007c). The EM-20 Roadmap Project managers have determined that the Hanford Analytical Services Quality Assurance Requirements Documents (HASQARD [DOE/RL-96-68]) apply to portions of this project and to selected subcontractors and collaborators. HASQARD requirements are discussed within applicable sections of this QAPjP. The PNNL document for implementing HASQARD for portions of this work is Conducting Analytical Work in Support of Regulatory Programs (CAWSRP), located at http://etd.pnl.gov/docs/conducting-work/index.stm.

\subsection{Special Requirements or Specifications}

DOE Orders 435.1, Radioactive Waste Management; 5400.5, Radiation Protection of the Public and Environment; and 450.1, Environmental Protection Program, apply to the project to ensure that activities related to radioactive materials and samples are protective of human health and the environment, and fulfill PNNL environmental and stewardship requirements. Compliance and waste-cleanup timetables and implementation milestones are established in the Tri-Party Agreement to achieve compliance with remedial action provisions of CERCLA and the treatment, storage, and disposal unit regulations and corrective action provisions promulgated under the Resource Conservation and Recovery Act of 1976 (RCRA).

Field experiment and sampling and analysis plans (see Sections 4.0 and 5.0) will be based on application of the Data Quality Objectives (DQO) process, in accordance with the Guidance on Systematic Planning Using the Data Quality Objectives Process (EPA QA/G-4) (EPA/240/B-06/001). Field experiment and sampling and analysis plans are reviewed and approved at the project level and updated as necessary.

Computer modeling and database activities for the project shall comply with the software requirements as specified in the PNNL's SBMS subject areas, “Software” (PNNL 2007h) and "Safety Software” (PNNL 2007f), as applicable. Specific safety software and software requirements for PNNL and collaborator activities are described in Section 17.0 and are based on a graded approach.

\subsection{Project Scope}

The scope of this QAPjP is to provide PNNL project staff and collaborators with the program-specific planning, execution, assessment of work, and controls necessary to provide services and products of the highest quality consistent with project risks, per the SBMS subject area, "Policies and Standards" (PNNL 2006b). Additionally, this QAPjP addresses the needs, expectations, and resources of the DOE-EM client. 
The purpose of the project is to develop new methods, strategies and technology for characterizing, modeling, remediating, and monitoring soils and groundwater contaminated with metals, radionuclides, and chlorinated organics. These objectives include computational, bench-scale, and field-scale activities, and engagement of stakeholders to guide technical direction and transfer results. This document also includes multiple-year planning efforts.

The initial child projects are briefly described as follows:

\subsubsection{Develop Advanced Fate and Transport Models - Conceptual and Numerical Model Development for High-Risk Contaminants and Sites (WBS 2.2.1)}

Accurate conceptual and numerical models are essential to cost-effective cleanup of soils and groundwater. Such models must address biogeochemical reactive transport for key contaminants; e.g., chlorinated organics, uranium, ${ }^{99} \mathrm{Tc},{ }^{90} \mathrm{Sr},{ }^{129} \mathrm{I}$, and plutonium. Models must also address hydrologic features (e.g., tight zones, fractured flow, etc.) that drive direction and flow, adding to model complexity. This task will integrate field and laboratory data into advanced conceptual and numerical models for radionuclides and chlorinated organics in the vadose zone and groundwater over the "lifecycle" of contaminated sites. This task will provide guidance and protocols for advanced conceptual and numerical models within time frames to significantly impact DOE decisions.

\subsubsection{Develop Approaches for Integrating Life-Cycle Monitoring Data into Site Models (WBS 2.2.2)}

Long-term monitoring and maintenance is one of the largest projected cost centers in the overall lifecycle of environmental management (though 2025); moreover, costs associated with the implemented systems will extend into future legacy management. Most cost is associated with frequent analyses of contaminants in a large number of monitoring wells. Such measurements are expensive and the resulting data sets are inefficient and inadequate for meeting long-term monitoring objectives.

The major objectives of this Work Breakdown Structure (WBS) element are to provide the following:

- In coordination with WBS 4.1.2, provide the technical basis to shift the existing paradigm of point-source monitoring to spatially integrated monitoring tools incorporating onsite field monitoring and sensors.

- Develop integrated risk management and decision support tools for a more system-based monitoring paradigm.

\subsubsection{Develop Advanced Remediation Methods for Metals and Radionuclide - Scientific and Technical Basis for in-situ treatment systems for Metals and Radionuclides (WBS 2.3.1.1)}

This project will generate both scientific information and cost effective in-situ remediation technologies needed to treat metals and radionuclide contamination at a number of waste sites in which the capacity of the natural system to attenuate the contaminants is exceeded. This problem is particularly challenging for deep vadose zone contamination at DOE sites in the arid western states where in situ technologies may be the only way to perform remediation if contamination is deep in the vadose zone and 
dispersing to associated groundwater. Primary metals and radionuclides of concern include ${ }^{99} \mathrm{Tc}$, uranium, ${ }^{90} \mathrm{Sr}$, plutonium, and chromium.

Remediation of deep vadose zone and associated groundwater contamination where the vadose zone thickness is relatively small will be more tractable than for sites where the vadose zone is relatively thick. At these latter locations, access for characterization, monitoring, and remediation becomes prohibitively costly as drilling depths increase. Thus, cost-effective in situ remediation is highly constrained and must maximize use of sustainable approaches, preferably using more passive systems based on use of geochemical manipulation to control mobility of contaminants. This approach requires an improved scientific basis for designing and demonstrating field systems that accounts for changing conditions over space and time. These conditions could include geochemistry, oxidation/reduction conditions, weathering, temperature (near tanks), biological transformation, or changing hydrologic conditions.

This project will use a core science and engineering team that engages scientific and engineering experts from across the nation. This team will work with sites to identify technical targets that describe the scientific and technical work elements necessary to address the project objectives. The team will also 1) align schedules with field activities to gain access to samples and information; 2) specify the most useful form of products to be delivered to the sites; and 3) ensure deep vadose zone access, monitoring, and remediation technologies are available within the time frames to impact site decisions.

The information derived from this project will improve the scientific knowledge about the contaminants and better understand their behavior in the natural system, providing key information via journal articles and technical guidance documents for designing and implementing remediation technologies. Additional products developed would be monitoring capabilities and strategies for vadose zone and groundwater environments.

\subsubsection{Demonstrate Methods to Reduce Transport Rate of Chlorinated Organics through Deep Vadose Zone (WBS 2.3.2.2)}

The chlorinated organics in the deep vadose zone component of the remediation initiative is focused on providing improved methods to control, reduce, or remove chlorinated organic contaminants in the vadose zone. Because transport of chlorinated organics in the vadose zone is a complex process, there are limitations in the current ability to characterize the distribution of existing contamination, predict future contaminant migration, and design and implement effective remediation methods. This project will examine vadose zone transport processes for chlorinated organics, identify improved remediation approaches, and provide guidance and methods to support setting and monitoring remediation objectives. Feasible remediation approaches for chlorinated organics in the deep vadose zone and groundwater will be identified that bridge from active remediation used in current baseline through alternative approaches and finally to monitored natural attenuation (MNA). A key linkage to related MNA and enhanced attenuation efforts will be incorporating consideration of vadose zone remediation in the context of reducing the contaminant mass flux as an enhanced attenuation approach to sustainably enable natural attenuation to address contamination within the corresponding groundwater plume.

\subsubsection{Columbia River Projects Follow-On Activities (WBS 2.5.0)}

DOE has conducted interim groundwater remedial activities at the Hanford Site since the mid-1990s for several groundwater contamination plumes. However, it is apparent these remedial activities have not 
reduced the risk to human health and the environment as quickly as was believed based on the risk assessments completed under RCRA and CERCLA; therefore, DOE established the Columbia River Supplemental Technologies Project in 2006 to evaluate alternative treatment technologies. Although these projects are now contained within the EM-20 Groundwater and Soil Remediation Program Multi-Year Program Plan, these projects will continue to be managed as PNNL project 50896 with a separate Project Management Plan (PMP) and Quality Assurance Project Plan (PNNL-16340, current revision). This decision was based upon the funding mechanism employed for the project (i.e., via DOE RL rather than the DOE Pacific Northwest Site Office). This decision may be revisited in the future if funding path and acquisition strategy changes.

The current goals and objectives for the Columbia River Projects Follow-On Activities include the following:

- Perform laboratory and field tests using long-chain polyphosphate material to stabilize uranium in groundwater, using results to determine cost-effectiveness (WBS 2.5.1 - 300 Area Uranium Plume Treatability Demonstration - U Polyphosphate Stabilization)

- Investigate use of Coyote willow along the Columbia River corridor to extract or isolate ${ }^{90} \mathrm{Sr}$ from the soil and incorporate it into above-ground biomass (WBS 2.5.2 - 100-N Area Sr-90 Treatability Demonstration [Phytoremediation])

- Determine the leaching characteristics of chromium from contaminated sediments from the 100 Area spill sites to determine possible chromium mineral and/or chemical associations that may be responsible for chromium retention, using results in a conceptual model for the Hanford 100 Area vadose zone (WBS 2.5.3 - Refine Location of Chromium Source)

\subsection{Change Control (Scope, Schedule, Budget)}

The project scope, schedule, and budget baseline are compiled, tracked, and reported using a project control system in accordance with direction from DOE-EM.

Changes in work scope, schedule, or budget may be necessary during the year. For those activities under PNNL control, changes may be requested of subcontractors and collaborators by PNNL that will result in a change to the statements of work (SOWs) due to revisions of work scope, schedule, and/or budget. These changes will be documented in revisions or addenda to the existing SOWs, and a PNNL Subcontract Supplement Form shall be completed.

Administrative changes requested of subcontractors and collaborators that are approved by the Project Manager may be made by verbal or e-mail authorization. Written documentation of the verbal changes and e-mail messages should be maintained in the permanent project files. These changes may only be made if technical work scope and budget are not significantly affected. 


\subsection{Project Organization and Responsibilities}

Line authority, QA authority, support within PNNL, and client interfaces are shown organizationally in Figure 3.1. The responsibilities of key personnel are summarized in Section 3.1. Changes to organizational/interface structures shown in Figure 3.1 that do not reflect a change in the overall scope of the activities, or a change of requirements, will not require a QAPjP revision and will be incorporated into the next required revision.

\subsection{Responsibilities of Key Personnel}

- Project Manager and Principal Investigator (PI) - Responsible for development and implementation of the Project Management Plan, Health and Safety Plan, and QAPjP. Serves as the primary-client interface to assure that customer expectations are met in terms of quality, cost, and schedule. Provides overall direction to project task managers and project personnel within PNNL necessary to accomplish project objectives; coordinates and executes project controls associated with scope, schedule, and budget baselines; reports on project status; assures that the project is staffed with technically qualified personnel, and assures the QAPjP is implemented.

- WBS Element Project Managers - Oversees task-specific planning, control, communications, and progress reporting; prepares scope, resource needs, cost baseline, and deliverables; assures quality and timeliness of work in accordance with plans, policies, and procedures; provides monthly reports; interfaces with DOE, other contractors, subcontractors, and other task managers.

- Investigators - Provides task-specific technical plans, communications, and progress reporting to the task manager; prepares technical details of the task plan; assures technical quality of the work; supports the task manager to assure work is performed on schedule, within budget, and in accordance with plans, policies, and procedures; assigns and directs work of project staff; interfaces with DOE, other contractors, subcontractors, and other investigators.

- Project Quality Engineer - Provides guidance and direction to Project Manager, task manager, and project staff within PNNL on PNNL QA program requirements; performs assessments to assure quality of the work; develops, updates, and approves the QAPjP; reviews and approves appropriate work plans and procedures.

- Other Project Staff - Assures technical quality of the work and that it is performed on schedule, within budget, and in accordance with plans, policies, and procedures; reports concerns such as unsafe conditions and stops work as necessary. 


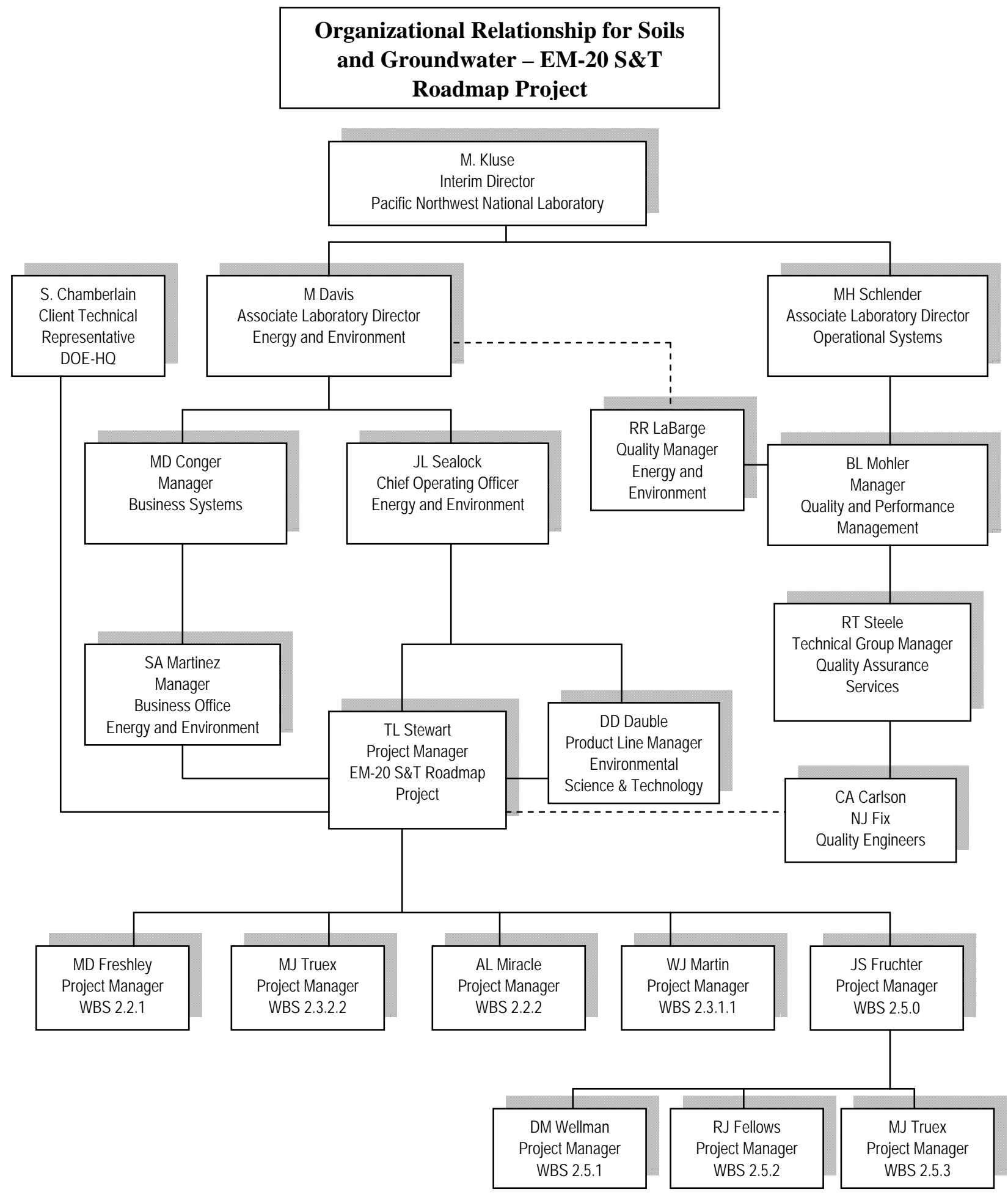

Figure 3.1. Organizational Relationships for the Soil and Groundwater - EM-20 S\&T Roadmap Project 


\subsection{Other Work Services}

Other work services for various portions of project work will be through the purchasing process. General scope statements, work requirements, specifications, and QA requirements are communicated via contracting mechanisms to various subcontractors (see Section 15.0). This project is considered scientific research by DOE-EM; however, one of the goals of the project is to transfer impactful science and models from the project to the Hanford Site remediation activities during and immediately after project completion. This information may be used in the selection of technologies for the remediation of sites under the Tri-Party Agreement. Therefore, SOWs and test plans used for groundwater and sediment sampling and analysis will require compliance with the HASQARD (DOE/RL-96-68) and/or the EPA Requirements for Quality Assurance Project Plans (QA/R-5) (EPA/240/B-01/003), and will specify requirements to be achieved by appropriate quality documents. The SOW will include instructions for inspecting/accepting supplies and consumables used for this project.

Subcontracts for drilling, sediment sampling, groundwater sampling, and associated support activities will include the following:

- Fluor Hanford, Inc. (FH) - Performs drilling, sediment and water-sample collection related to drilling, and well construction services.

- Other subcontractors - May provide civil surveys, special analytical services, or other services.

\subsubsection{Analytical Services}

Project participants at PNNL and other DOE national laboratories are responsible for preparing data reports that summarize the results of analyses and detailed data packages that include the following:

- Sample receipt and tracking documentation, including identification of the organization and individuals performing the analysis; names and signatures of the responsible analysts; sample holding time requirements; references to applicable chain-of-custody procedures; and dates of sample receipt, extraction (if applicable), and analysis.

- Quality control data, as appropriate for the methods used, including (as applicable) matrix spike/matrix spike duplicate data, recovery percentages, precision and accuracy data, laboratory blank data, and identification of any nonconformance that may have affected the laboratory's measurement system during the time period in which the analysis was performed.

- Analytical results or data deliverables, including reduced data and identification of data qualifiers and contractually defined reporting comments.

These requirements, as well as QA and technical requirements, are specified in the SOW to the other national laboratories and university project participants as necessary.

\subsubsection{Sampling}

The organization collecting soil or water samples—generally PNNL—is responsible for 1) obtaining the samples; 2) delivering samples to the laboratory; and 3) delivering completed paperwork to implementing sample tracking. All activities associated with the sample collection, sample handling, sample labeling, and custody of the samples in the field shall be consistent with the recommendations and 
protocol provided in Chapter 4, Section 4.2 through 4.4 in the RCRA Ground Water Monitoring Technical Enforcement Guidance Document (National Water Well Association 1986); Test Methods for Evaluating Solid Waste: Physical/Chemical Methods, SW-846, Third Edition (EPA/SW-846), and the Handbook for Analytical Quality Control in Water and Wastewater Laboratories (EPA-600/4-79/019). Activities associated with the sample collection, sample handling, sample labeling, and custody of the samples in the field shall be consistent with the SOW.

\subsubsection{Well Drilling, Sampling, and Construction Services}

FH provides well-drilling and construction subcontractors, and oversight of specific work activities at the Hanford Site. For the EM-20 Roadmap Project, FH is responsible for 1) well-drilling design specifications and contract management; 2) site preparation and documentation requirements; 3) sediment and water sample collection during drilling; 4) supporting hydrologic tests conducted during drilling; and 5) well construction, development, and sample pump installation. Well construction activities shall meet Washington Administrative Code 173-160 requirements. Well drilling and construction, sediment and water sampling, testing support, and associated quality requirements will be specified in the SOW to FH. FH may subcontract work activities, provided the requirements in the SOW and the FH QA Program are met by subcontractor(s).

\subsubsection{Geophysics}

FH is responsible for obtaining geophysical logging services during well drilling activities. PNNL provides technical support to FH to ensure that the geophysical logging requirements and associated quality requirements are specified in the SOW. The requirements for the data deliverables are also specified in the SOW.

Other geophysics activities are provided by PNNL and external collaborators on the EM-20 Roadmap Project. PNNL and/or the collaborators are responsible for performing these geophysical services. PNNL provides technical support to the collaborators to ensure that the requirements and associated quality requirements and data deliverables are specified in the SOW to the proposed subcontractor.

\subsubsection{Field Measurements}

Field measurements during well drilling will be conducted in accordance with FH procedures during well drilling, or other equivalent procedures, and as directed in the SOW. EM-20 Roadmap Project-specific test plans that have been reviewed and approved will address procedures during field experiments.

\subsubsection{Other Services}

Other subcontracted services received from FH or other Hanford Site contractors may include construction of fences and enclosures, geophysical logging, etc.

\subsection{Work Conducted by Project Staff}

Analytical activities conducted by staff in support of the EM-20 Roadmap Project shall be conducted in accordance with written standard operating procedures documented in test plans associated with 
experiments, as appropriate. Field measurements will be conducted in accordance with in-house operating procedures. The project staff members are responsible for preparing data reports that summarize the results of analyses, quality control data for the method used, and identification of data qualifiers. Results and raw data will be included in the project records.

Project staff will perform sampling and measurements according to written and approved test plans (Section 5.1), written procedures, or other written direction.

\subsection{Field Work}

Field work is a component of the EM-20 Roadmap Project. Prior to executing field work, project-specific test plans are developed as described in Section 5.0. If supplemental information or individual parameters are needed to perform a test, a test instruction will be developed. The test instruction shall be reviewed by technical staff and the project Quality Engineer.

Field work associated with task activities is conducted in accordance with the Surface Environmental Surveillance Procedures Manual (PNL-MA-580; current revision). The following procedures in PNL-MA-580 are used:

- Section 4.1, “Grab Samples”

- Section 4.6, "Sampling Columbia River Riverbank Springs”

- Section 4.8, "Specific Conductance"

- Section 4.9, “pH Measurement”

- Section 4.10, "Water Filtration"

- Section 8.1, “Trip Sheets.”

\subsection{Data Quality Objectives}

The QA objectives for measurements generally applicable to technology investigations under the purview of this QAPjP are primarily related to the following: 1) the definition of appropriate methods and analytical precision and accuracy appropriate for chemical analysis of the analyte of interest; and 2) the definition of methods and limits and values for physical measurements associated with the investigation (e.g., column tests). Discussions of aqueous sample analytical objectives and analytical methods with corresponding target values for detection limits, precision, and accuracy are provided in Appendix A of this QAPjP, the Environmental Sciences Laboratory QA Plan (ESL QAP; current revision), individual test plans, and/or test procedures. Sediment analytical objectives and analytical methods with corresponding target values for detection limits, precision, and accuracy are provided in the ESL QAP, individual test plans, and/or test procedures. DQOs developed in accordance with Guidance on Systematic Planning Using the Data Quality Objectives Process (EPA QA/G-4) (EPA/240/B-06/001) will be applied. Other measurement objectives and methods with corresponding target values for detection limits, precision, and accuracy (as applicable) are provided in the specific work plans and/or the SOW for such activities. Specific data quality needs for individual investigations that are different than the requirements established herein shall be addressed within individual work plans. Other measurement considerations, accuracy requirements, units, and data recording and reporting protocols for instruments 
supporting stratigraphic characterization, aquifer testing, and other types of field investigations shall be as specified in the applicable plans and/or procedures.

\subsection{Test Plans and Procedures}

Test plans and procedures are used to assure that activities affecting quality are performed consistently and correctly. Test plans are prepared by project staff to conduct a single experiment or test as identified below. In particular, individual field experiments will require a written test plan, reviewed and approved by the Project Manager and Quality Engineer. Formal procedures will be developed for quality affecting work activities that are routinely performed. Additional procedures will be developed as needed.

\subsection{Test Planning and Performance}

Test plans will be used to document a single or related set of experiments or tests (e.g., hydrologic field tests, vertical sampling) work activity.

\subsubsection{Developing the Test Plan}

The test plan shall contain the following information:

- A title and/or number including date or revision.

- Dated signatures of the preparer, technical lead, Project Manager or task manager, and Quality Engineer.

- Individual page identification (page __ of __ ).

The content of each test plan will depend on the scope of the test. The following is a brief description of mandatory and optional items to be considered in the preparation of the test plan:

- Purpose/Description (mandatory) - Provide a short narrative on the purpose of the experiment/test/activity.

Example: The purpose of this test is to provide hydrologic property data at polyphosphate treatability injection test wells.

- Prerequisites (mandatory) - List items, conditions, or other concerns that must be satisfied prior to beginning the test.

Example: Prior to beginning the work activity, the staff must complete special training on other plans or procedures that will be used in conjunction with the test plan, special handling or storage requirements, special access or permits, and required records that need to be generated as the result of the work activity.

- Safety (mandatory) - Describe the hazards associated with the work such as physical agents (e.g., temperature, pressure, noise, electrical); hazardous environments (e.g., confined spaces, remote locations, heat/cold stress); and hazardous materials (e.g., flammables, corrosives, highly toxic

chemicals, carcinogens). Describe the methods used to mitigate the hazards that were identified (e.g., 
personal protective equipment, time periods away from the hazard, alarms, location of nearest aid station).

- Materials and Equipment (optional) - List the materials and equipment necessary to complete the work.

- Measuring and Test Equipment (mandatory) - List the equipment that will be used to make the measurements; include the calibration requirements, system checks, and quality control checks in this section or in the work instructions section of the test plan.

- Pretest Verification (mandatory) - Determine if certain items of a test require verification prior to their use and indicate how the verification will be done.

Example: A tracer solution containing $\mathrm{Br}$ will be used throughout the test and the initial concentration shall be known. The solution shall be measured by the calibrated probe (as described above) and the concentration shall be recorded prior to injection.

- Documentation and Reporting (mandatory) - Describe where the data collected during the test should be documented (e.g., field record forms, LRBs, entered into a computer, downloaded from computer to hardcopy). Additionally, describe what will be reported, to whom, and the due date(s).

- Work Instructions (mandatory) - Provide step-by-step instructions and/or non-sequential instructions (whichever is more appropriate to the activity). Each step or instruction shall be as simple as possible but with sufficient detail so that individuals experienced in the technology or activity involved can easily understand. The following types of information should be considered for inclusion: administrative-control hold points (i.e., where safety, quality, radiological, or other approvals or actions are required before proceeding); cautions that indicate potentially hazardous situations which, if not avoided, may result in death, injury, or damage to facilities or equipment; and notes that call attention to supplemental information that assist the user in making decisions or improving work performance.

\subsubsection{Test Performance}

Tests will be performed in accordance with the test plans, which shall be available at the work location. The Technical Lead is responsible for assuring that the current version is used to perform the work.

If changes to the test plan are required during the execution of the work, the Technical Lead shall document the deviation and the justification or rationale for the change.

\subsection{Procedures}

Procedures will be developed in accordance with the SBMS subject area, "Procedures, Permits, and Other Work Instructions” (PNNL 2004). Project staff will perform scheduling, data verification, data processing, and data management as described in Section 6.0 and by following the applicable internal technical procedures or instructions. 


\subsubsection{Project Procedures}

Procedures used by PNNL project staff will be developed in accordance with the SBMS subject area, "Procedures, Permits, and Other Work Instructions" (PNNL 2004). Project staff will perform scheduling, data verification, data processing, and data management as described in Section 6.0 and by following the applicable internal technical procedures or instructions. Also, project staff will perform groundwater sampling, field measurements, water-level measurements, and aquifer testing by following the appropriate internal technical procedures.

\subsubsection{Water-Level Procedures}

Procedures for water-level measurements shall be written in accordance with industry-accepted standards, such as guidelines prepared by the U.S. Geological Survey (1977), and updated as required for the latest advances in measuring equipment.

\subsubsection{Analytical Procedures}

The specific work plans and/or test plans identify the constituents to be analyzed. As applicable, a PNNL internal procedure generates the sampling package (e.g., chain-of-custody form), which identifies the analytical methods, sample identification, etc. on the chain-of-custody form. The chain-of-custody form and samples are provided to the appropriate analytical laboratory. Administrative QA processes and procedures (e.g., chain-of-custody, custody logs, sample handling, storage and disposal, training) will be required of the onsite and offsite analytical laboratories and will be specified in the SOW. The analytical methods required may be contained within the following references:

- Test Methods for Evaluating Solid Waste: Physical/Chemical Methods, SW-846, Third Edition (EPA/SW-846, as amended)

- Methods for Chemical Analysis of Water and Wastes (EPA-600/4-79-020)

- Methods for the Determination of Organic Compounds in Drinking Water (EPA-600/4-88-039)

- Prescribed Procedures for Measurement of Radioactivity in Drinking Water (EPA-600/4-80-032)

- Procedures for Radiochemical Analysis of Nuclear Reactor Aqueous Solutions (EPA-R4-73-014)

- Radiochemical Analytical Procedures for Analysis of Environmental Samples (EMSL-LV-0539-17).

Many radiochemical methods have not been standardized, but the procedures are documented in laboratory-specific standard operating procedures. Aqueous sample chemical and radiological analytical methods and requirements for constituents are specified by the SOW, work plan, or other written direction.

Most potential chemical constituents to be analyzed are provided in Appendix A, Table A.3 of this QAPjP and/or the Environmental Sciences Laboratory QA Plan (ESL QAP, current revision). Sediment and other media constituents to be analyzed and corresponding analytical methods and procedures will be passed on to the analytical laboratory by a SOW, work plan, or other written direction.

Method detection limits (MDLs) shall be determined for all non-radiochemical methods required by the project. Water MDLs shall be determined in accordance with 40 CFR 136, Appendix B, "Definition and Procedure for the Determination of the Method Detection Limit-Revision 1.1.” The Laboratory 
provides MDL studies results to PNNL as specified in the SOW. Required detection limits for radiochemical methods are provided in the SOW, work plan, or other written direction.

Sediment constituents to be analyzed for as well as the corresponding analytical methods and procedures will be passed on to the analytical laboratory by a SOW. The MDLs for sediment analysis shall be determined using the calculation provided in Chapter 1 of EPA/SW-846, as amended.

Technical procedures not previously documented will be developed and used as described in CAWSRP, Section 7, "Procedures.” If supplemental information or individual parameters are needed to perform a test, a test instruction will be developed. The test instruction shall be reviewed by a technical reviewer and must include the following information:

- A unique numerical designation

- Revision number

- Title

- Effective date

- Instructions - operating parameters and specific test run information such as sample size and/or composition, temperature, $\mathrm{pH}$, test duration, etc.

- Reference to controlling procedure or test plan

- Approval by author

- When well-established methods (e.g., American Society for Testing and Materials [ASTM], Soil Science Society of America, or U.S. Environmental Protection Agency) are used, a PNNL cover page will not be provided unless there is a deviation from the established method.

Appendix B of this QAPjP lists additional analyses and measurements with the respective procedures, methods, and other relevant information.

Administrative QA processes and procedures (e.g., chain-of-custody, custody logs, sample handling, storage and disposal, training) will be required from the onsite and offsite analytical laboratories and will be specified in the SOW.

\subsubsection{Calibration Procedures}

The requirements for calibrating field and analytical laboratory instruments and maintaining traceability to national or international standard (e.g., National Institute of Standards and Technology) is in accordance with Test Methods for Evaluating Solid Waste: Physical/Chemical Methods (EPA/SW-846) and HASQARD (DOE/RL-96-68). These requirements are passed to the subcontractors by a SOW. PNNL will periodically assess the use and effectiveness of procedures and systems for calibration of equipment with the subcontractors.

Measuring and test equipment (M\&TE) used by PNNL staff to collect quality-affecting data that are calibrated by the user (Category 2 M\&TE) or by an approved external or internal source (Category 1 M\&TE) will be in accordance with the SBMS subject area, “Calibration” (PNNL 2005b). Upon receiving calibrated equipment, staff must review the documentation for acceptability and verify the proper operation of the M\&TE and check the calibration label. 
M\&TE shall be controlled as described in CAWSRP, Section 4, "Instrument Calibration," and in accordance with the SBMS subject area, “Calibration” (PNNL 2005b). Externally calibrated M\&TE, such as balances, will be calibrated in accordance with manufacturer's tolerances unless other control limits are specified and justification is provided.

Data sheets and log book entries will be used to document pipette performance checks. Calibration reports and other calibration data will be maintained as project records.

Quality control requirements are described in CAWSRP, Section 5, “Quality Control," and in Appendix A of this QAPjP. A few exceptions to CAWSRP requirements are considered necessary for the project, as described in the following sections.

\subsubsection{Common Data Quality Calculations}

Data quality parameters of precision, accuracy, measures of agreement, detection limits/sensitivity, and uncertainty will be calculated per the formulas in CAWSRP, Section 6, in the exhibit "Calculations for Assessing Data Quality.” For radiochemistry analyses, the minimum detectable activity (MDA) is reported as the detection limit.

The CAWSRP exhibit, “Calculations for Assessing Data Quality,” provides a control charting tool used to monitor an ongoing/continuous process where there are sufficient data points to perform a representative statistical evaluation. The analyses performed within this project are performed as a research function in which instrumental operating parameters may be changed to accomplish many different objectives. The frequency of instrumental operating changes does not allow accumulation of sufficient data points to properly utilize control charting as a statistical analysis tool. In lieu of control charts, instrument performance is monitored daily by the use of fixed control limits.

\subsubsection{Well Drilling and Construction Procedures}

FH will obtain drilling services that are necessary through their procurement process. SOWs to FH will be used to specify well drilling, characterization (aquifer and sediment sampling, etc.) and construction requirements. The well drilling, sediment samples collection, groundwater samples collection, water level measurements, and notification to perform geophysical logging/gyroscope well deviation surveys are the responsibility of FH. These activities will be performed to FH procedures and/or to subcontractor procedures (e.g., conducting geophysical logging/gyroscope well deviation survey). FH Health and Safety, and QA procedures and waste management procedures will be followed during the drilling activity.

\subsubsection{Water and Sediment Sample Collection Procedures}

Water and sediment sampling within this project will be done by EM-20 Roadmap Project personnel. To assure that samples of known quality are obtained, project staff will be required to use controlled procedures based on standard methods for groundwater sampling whenever possible. Assessments will be performed by PNNL to further assure that procedures are followed to maintain sample quality and integrity (see Section 8.0). 
Sediment and water samples collected during drilling will be collected by or under the direction of $\mathrm{FH}$, and in accordance with $\mathrm{FH}$ or subcontractor procedures. The quality requirements for sampling activities, including chain-of-custody, storage, and records requirements are specified in the SOW (or well data sheet). Scheduling sample bottle preparation, sample analysis, and preparing associated paperwork is conducted by PNNL in accordance with PNNL internal procedures.

\subsubsection{Receiving and Handling Samples}

Direction for sample handling and storage is provided in CAWSRP, Section 3, "Receiving and Handling Samples," and in the SBMS subject area, "Sample Handling, Archival, and Disposal” (PNNL 2007g).

Chain-of-custody for samples will be documented using a chain-of-custody form. An example of a chain-of-custody form is provided as an exhibit in CAWSRP. Each PNNL facility is a secured area, restricted to authorized personnel only. Chain-of-custody will be documented for moving samples from one facility to another, but not for moving samples within a secured facility.

The samples to be received from other PNNL groups are materials from various field investigations. Documentation of unique sample and subsample identifications will be maintained for samples received from other PNNL groups, and for other samples generated from tests conducted by the project. The documentation may consist of entries in LRBs or data sheets.

Disposition of unused materials may include returning the material to another group at PNNL, the client, or disposal at PNNL. Material returned to the client will be documented by a chain-of-custody form. Material disposed at PNNL will be documented by standard waste paperwork (forms). See SBMS subject area, “Waste, Managing” (PNNL, 2007i).

\subsubsection{Sediment Physical Analysis Procedures}

Sediment physical analyses including moisture content, particle-size distribution, hydraulic conductivity, water retention, water content, bulk density, particle density, and matric potential will be performed as directed in test plans developed by PNNL staff. Sediment physical analysis procedures are described in the internal Procedures for Groundwater Investigations (PNL-MA-567) or on projectspecific internal procedures for groundwater.

\subsubsection{Sediment Core Analysis Procedures}

Sediment core analyses and column experiments will be performed by PNNL staff as directed in test plans. The individual test plans will either provide a written procedure or reference an existing procedure.

\subsubsection{Geophysical Logging Procedures}

Geophysical logging and gyroscope well deviation surveys during well drilling will be performed through subcontract with FH, using their procedures, and as directed in the SOW. All other geophysical logging procedures will be performed according to documented test procedures. 


\subsection{Data Generation and Acquisition}

\subsection{Experimental Design (Sampling Process Design)}

Data generation and data collection designs for the EM-20 Roadmap Project experiments will be documented in individual test plans.

Sampling processes used to support EM-20 Roadmap Project studies will be in accordance with the waste management area sampling design, based on the regulatory requirements (e.g., RCRA or CERCLA) and will apply the DQO process in accordance with Guidance on Systematic Planning Using the Data Quality Objectives Process (EPA QA/G-4) (EPA/240/B-06/001). A description of these processes will be included in test plans along with the number of samples, sampling schedule, number of sample locations, number of quality control samples (field replicates, etc.), analysis methods and quality control criteria, and the groundwater level measurements.

\subsection{Sampling Methods}

The procedures for collecting samples and identifying the sampling methods and equipment, including any implementation requirements, sample preservation requirements, decontamination procedures, and materials needed for projects involving physical sampling are described in the EM-20 Roadmap Project study-specific work plans and procedures. If a failure in the sampling or measurement system occur, documentation of and recovery from the failure will be documented in the project-specific LRB or controlled field book. The EM-20 Roadmap Project Manager is responsible for ensuring corrective actions are effective and documented.

The preparation and decontamination of sampling equipment, including the disposal of decontamination by-products; the selection and preparation of sample containers, sample volumes, and preservation methods; and maximum holding times from sample extraction to analysis will be managed in accordance with EPA/SW-846 (1986, as amended) or PNNL-specific procedures, as applicable. Waste generated as a result of the activities will be handled in accordance with SBMS subject area, "Waste, Managing” (PNNL 2007i).

\subsection{Sample Handling and Custody}

Custody of the samples collected by EM-20 Roadmap Project staff in the field and receipt at the laboratory will be documented on the chain-of-custody forms in accordance with PNNL procedures. Additionally, shipping and transporting of the samples will be handled by PNNL staff in accordance with PNNL procedures and federal regulations, and the SBMS subject area, "Hazardous Materials, Packaging and Shipping” (PNNL 2007a).

\subsection{Analytical Methods}

The sampling and analysis plan for each site will identify the sample constituents and the analytical methods as described in Section 5.2.3. 


\subsection{Data Reduction, Verification, and Reporting}

\subsection{Data Reduction}

Data measured during project investigations are compiled, evaluated, and documented as described in the following paragraphs. Samples and associated analyses are scheduled and tracked to assure successful sample collection. Selected data will be loaded into the EM-20 Roadmap Project database, as identified in the individual test plans.

Verification of analytical data is performed, as appropriate, in accordance with Appendix A of this QAPjP. Results are reviewed to assure the reliability and validity of the field and laboratory measurements based on accuracy, precision, and detection limits. Representativeness, completeness, and comparability may also be evaluated for overall quality. These parameters are evaluated through laboratory QC checks, replicate sampling and analyses, analysis of blind standards and blanks, and/or inter-laboratory comparison. Acceptance criteria are established for each of these parameters in Appendix A of this QAPjP, the Environmental Sciences Laboratory QA Plan (ESL QAP; current revision), and/or in specific test plans. When parameters are outside acceptance criteria, corrective actions are taken to prevent a future occurrence and any data impacted are appropriately flagged.

When a data review identifies suspect data, those data are investigated to establish whether they reflect true conditions or an error. A Review Document Record (RDR) form is initiated in accordance with the procedure DA-3, "Data Review Procedure” (see PNL-MA-567) or other appropriate project-specific method.

\subsection{Sample Data Tracking and Verification}

The process for tracking and scheduling sampling and analysis requirements, sampling field activities, chains-of-custody, and laboratory analysis is managed using a variety of electronic data management tools. Data are received from the laboratories in electronic and hard copy form.

A central, web-accessible database for all samples, characterization measurements, and experimental data, which enables remote collaborative efforts, will be used if warranted. Raw data, sampling metadata, and instrument calibrations will be stored to allow an auditable, reproducible link between field measurements and finalized data. If warranted, wells and sensors will be linked to an automated data acquisition infrastructure that will utilize a dedicated wireless network. The same network will support an electronic notebook and the deployment of temporary monitoring stations.

\subsection{Sample Data and Tracking for Sediment and Other Media Samples}

Analytical data developed for sediment and other media samples will be verified by EM-20 Roadmap Project personnel prior to loading into the database or reported. Verification will consist of reviewing data for completeness, required QC results, chain-of-custody forms, and case narratives that describe any issues related to the sample analyses. Verification may also include evaluating and qualifying results based on holding times, method blanks, matrix spikes, control samples, duplicates, and chemical and tracer recoveries, as appropriate to the methods used. No other verification/validation or calculation checks will be performed. At least $10 \%$ of all data types (i.e., radionuclides, metals, etc.) will be verified. Verification will be documented on checklists to be included in the project files. 


\subsection{Data Reporting}

Data measured during the EM-20 Roadmap Project are compiled, evaluated, and documented as described in the following paragraph. When the data review identifies suspect data, those data are investigated to establish whether they reflect true conditions or an error.

All data reported shall be traceable to the measuring and test equipment and procedure (including procedure revision) or test plan used, and if the reported results are quantitative, a valid calibration. The analyst shall sign or initial and date the data reports unless the results printed by the instrument include identification of the analyst and date. A staff member other than the person who performed the work, and who is knowledgeable in the area being reviewed, shall review the data before results are reported. Interpretative data, test results, and reports will be released through the information release process in accordance with the SBMS subject area, "Publishing Scientific and Technical Information” (PNNL 2007d).

\subsection{Analytical Quality Control Checks}

Analytical quality control (QC) checks are performed on internal and external samples. A summary of QC check samples is outlined in Appendix A of this QAPjP, the Environmental Sciences Laboratory QA Plan (ESL QAP, current revision), and/or in specific test plans. Internal QC data are generated when the analytical laboratory staff prepares QC samples to monitor the quality of their analyses.

The QC activities needed for sampling, laboratory (internal and external) and field analysis, or measurement technique will be defined in the appropriate EM-20 Roadmap Project test plans. For each required QC activity, the associated method, acceptance criteria, and corrective action will be listed. Also, for the field and laboratory QC activities included, but not limited too, are the use of blanks, duplicates, matrix spikes, laboratory control samples, and surrogates in the plans. The project-specific QA Plans also identify the procedure, formulae, or references for calculating the percent recovery, bias, and precision.

\subsection{Assessments}

Assessments are performed to gather results that can be evaluated to measure the effectiveness of the quality systems and processes implemented by the EM-20 Roadmap Project. Assessments will be performed periodically during the year. The following types of assessments may be used at varying frequencies during the year:

- Management self-assessment - An assessment performed by those immediately responsible for overseeing and/or performing the work to establish whether policies, practices, and procedures are adequate for assuring results needed.

- Management independent assessment — An assessment performed by an individual or group independent of the work performed to assure that policies, practices, and procedures are adequate for assuring results needed. 
- Technical independent assessment - An assessment performed by an individual or group technically competent to perform the work but independent of the work being performed to assure qualitative and quantitative aspects of the work are accomplished according to documented specifications.

Data quality assessments are conducted as project QC checks. The focus of data quality assessments is independent verification of reported results. Data quality is routinely evaluated through technical review. If the complexity and/or significance of the work performed warrants it, the Project Manager will direct the QA representative and/or another staff member to conduct an additional quality assessment. The assessment is documented and retained in the project records. Documentation of the above assessments, as well as any external assessments performed is maintained as project records. The Project Manager is responsible for ensuring that any deficiencies are corrected in a timely manner.

\subsection{Assessment Planning and Documentation}

The project management team (including Project Manager, technical leads, and appropriate project staff) plans assessments in consultation with the project Quality Engineer. An assessment schedule will be developed by the project Quality Engineer with Project Manager approval. Assessments may be performed by the project staff, project management, and/or the Quality Engineer in accordance with the SBMS subject area, "Planning, Assessment, and Analysis," Section 2, "Performance Assessment" (PNNL 2007b). The assessor plans the assessment on a Self-Assessment Planning Form (see example in Figure 9.1) where the scope of the assessment, topic, and supporting references are documented on the plan. A unique identification number is assigned to the plan and entered on an Assessment Log Sheet. The Project Manager (or delegate) approves the plan.

Results of assessments will be documented on a Self-Assessment Results form (see example in Figure 9.2). The corrective action and action owner will be documented on the assessment report. The action owners will be assigned by the Project Manager (or delegate). An action item log will be maintained by the project Quality Engineer to track and close out actions. The Project Manager will prioritize the corrective actions. The corrective actions will be verified by the project Quality Engineer. When the corrective actions have been closed, the Project Manager will sign the assessment report. The assessment plan and report will be distributed to the appropriate staff, Project Manager, and project records.

\subsection{Subcontractor/Collaborator Assessments}

PNNL subcontracted work will be periodically assessed as an oversight function or prior to contract award in accordance with the internal acquisition quality procedures. Provisions are made in the SOW for oversight assessment activities to be performed as necessary. The results of all subcontractor/ collaborator assessments (including surveillances and audits) will be made available to project and line management, individuals contacted, and the client as requested. The corrective action tracking, corrective action and closure response will be in accordance with the internal acquisition quality procedures. The official assessment report files and responses (audits and surveillances) are maintained in the PNNL Suppliers History File by the Quality Assurance Services group.

Periodic assessments of the well drilling and construction, drilling and sampling-related activities, and the ESL may also be performed in accordance with the requirements in this section. 


\section{SELF-ASSESSMENT PLANNING FORM}

\begin{tabular}{|l|l|}
\hline Scope \& Location: (General: Maintenance, Operations, & $\begin{array}{l}\text { I.D. Number: (Assessment tracking system number or other } \\
\text { unique tracking number) }\end{array}$ \\
\hline Topic: (Describe what will be assessed) & Date: (Date planning form is prepared) \\
\hline $\begin{array}{l}\text { References: (Cite source documents for performance expectations; i.e., regulation, environmental permit, DOE Order, } \\
\text { A-Manual, Standards Based Management System, [SBMS], or requirements, procedures and guidelines [RPG]). }\end{array}$
\end{tabular}

\section{Performance Expectations}

Criteria developed from source documents that will be applied throughout the assessment. Each criteria/expectation will have the reference enclosed in parenthesis at the end of the criteria/expectation statement (e.g., DOE O 5480.19, SBMS, RPG). Performance expectations should be limited to six maximum to allow the assessment to remain focused. Additional planning forms can be completed to expand the scope of a particular assessment.

\section{1.}

2.

3.

4.

5.

6.

Procedure: (Perform the following as applicable for the assessment)

Review assessment planning form

- Review applicable procedure/requirements. (Include references.)

- Conduct performance tests and data validation.

- Observe the activity controlled by the procedure.

- Interview appropriate personnel about requirements and practices.

- Record observations based on comparison to plan.

- Document the results after receiving final information on the Self-Assessment Results form.

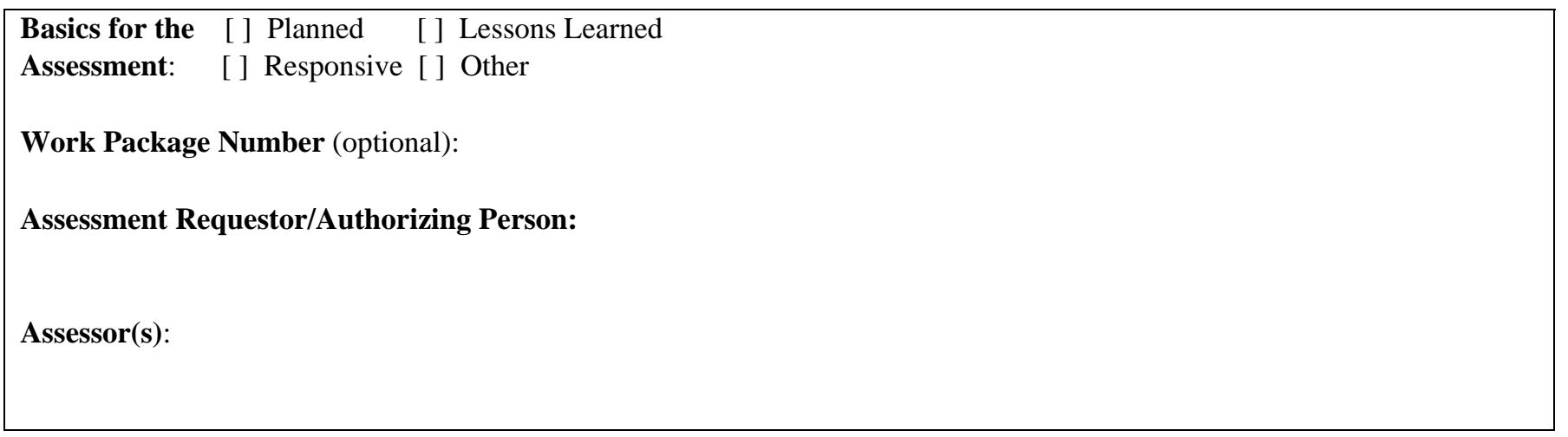

Figure 9.1. Self-Assessment Planning Form 


\section{SELF-ASSESSMENT RESULTS}

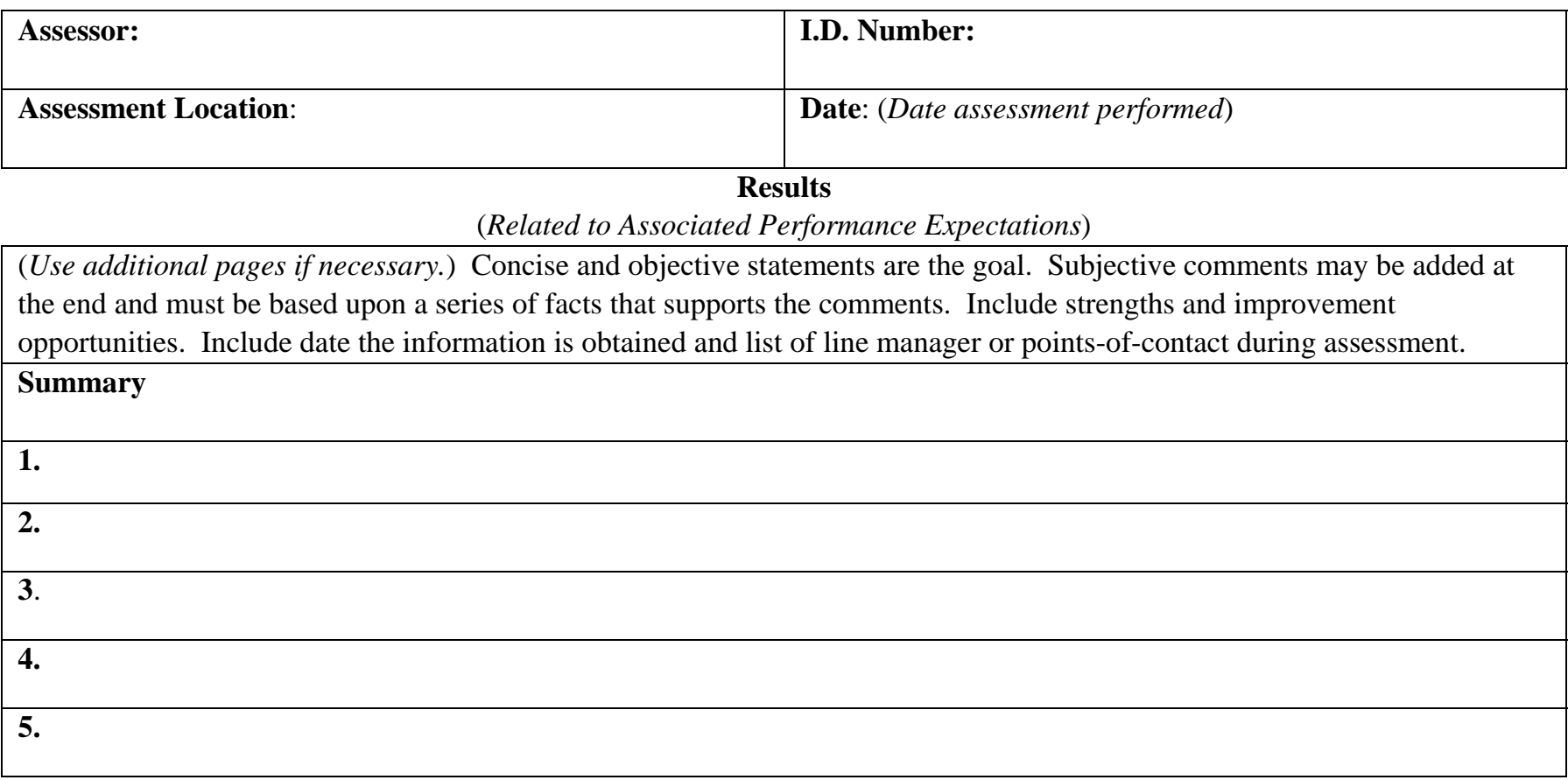

Subsequent Actions

(Related to Associated Results)

\begin{tabular}{|l|l|l|}
\hline \multicolumn{1}{|c|}{ Assigned Action } & \multicolumn{1}{|c|}{ Action Owner } & Due Date \\
\hline $\mathbf{1 .}$ & & \\
\hline $\mathbf{2 .}$ & & \\
\hline $\mathbf{3 .}$ & & Date: \\
\hline $\mathbf{4 .}$ & & \\
\hline Actions Assigned By: & \\
\hline $\begin{array}{l}\text { Completion (To be signed by Lead Assessor when assessment is completed.) } \\
\text { Signature: } \\
\text { Date: }\end{array}$ \\
\hline $\begin{array}{l}\text { Completion (To be signed by Manager when assessment is completed and all actions have been entered into ATS) } \\
\text { Signature: } \\
\text { Date: }\end{array}$
\end{tabular}

Figure 9.2. Self-Assessment Results 


\subsection{Preventive Equipment Maintenance}

Subcontracted organizations and collaborators will be required to implement preventive maintenance of their equipment to mitigate the possibility of down time affecting cost and schedule. This will be specified in the SOW to the respective organizations.

\subsection{Specific Routine Procedures Used to Assess Data Precision, Accuracy, and Completeness}

The evaluation of laboratory precision, accuracy, and completeness is accomplished during the verification process performed upon receipt of data (see Section 7.0 of this QAPjP).

\subsection{Corrective Action}

\subsection{Project Corrective Actions Resulting from Assessments}

As part of the continuous improvement processes initiated by the project management team, assessments will be tracked and improvement actions identified and prioritized. The Assessment Tracking System (ATS) is the process used by this project for tracking and managing assessments, including determining conditions and action development. ATS supports the identification, control, and correction of items, services, and processes that do not meet established requirements. The SBMS subject area, “Assessment Management” (PNNL 2005a) documents this corrective action management process for handling and documenting events and assessments, including those that must be tracked in ATS such as formal project reviews or audits performed by the client or their representative, and management-initiated assessments. If immediate corrective action is required, the quality problem will be directly entered into the ATS and actions taken as specified in Section 12.2.

\subsection{Unplanned Deviations}

Corrective action must be initiated by the Project Manager or cognizant Task Manager when unplanned deviations from procedural, contractual, regulatory requirements or construction specifications occur. These deviations will be recorded by documenting the quality problem information directly into the ATS in accordance with the SBMS subject area, "Quality Problem Reporting” (PNNL 2005c). The assessment must describe the problem, cause of the deviation, impact of the problem, and corrective action needed to remedy the immediate problem and prevent recurrence.

Subcontractors/collaborators will be required to have systems in place to identify, correct and prevent recurrence of contractual, procedural or regulatory requirement(s) deviations, and to notify the PNNL point-of-contact specified when such an event occurs. These requirements will be passed on in a SOW to the subcontractors. 


\subsection{Planned Deviations}

Planned deviations from procedure, documented (including justification) and approved by the Project Manager or Task Manager in advance, do not constitute a deficiency and do not require generation of an assessment item. Documentation may consist of a hard copy e-mail or memo to the Project Manager or Task Leader. This documentation must include either an approval signature if on a memo, or electronic approval via reply to the e-mail indicating such approval.

\subsection{Measuring and Test Equipment Calibration Discrepancies}

Subcontractors will be required to maintain a system for identifying calibration discrepancies and tracing data or samples that may have been affected. Subcontractors will be required, via their SOW, to notify the PNNL point-of-contact as soon as possible when such an incident occurs. PNNL will perform periodic assessments to assess the effectiveness of subcontractor procedures and processes for calibration control.

Project staff must investigate instruments or equipment found to be operating outside acceptable operating ranges (as specified in the applicable technical procedure or manufacturer's instructions), and issues must be addressed in accordance with the SBMS subject area, "Quality Problem Reporting” (PNNL 2005c). When as-found data on an instrument's calibration report was found to be "Out of Tolerance" during the review and acceptance process of the contract-supplier documents submitted in response to quality requirements, an Out-of-Tolerance Notification will be generated using the ATS in accordance with the SBMS subject area, “Assessment Management” (PNNL 2005a). Project staff must then determine if there was any impact on data. When it is determined from calibration verification that Category 1 or 2 M\&TE is out of tolerance, project staff shall proceed with the evaluation to determine impact on data and document the results with appropriate justification.

\subsection{Quality Assurance Reports to Management}

Quality activities such as project improvement efforts, significant deficiencies identified, associated corrective actions, and summary of assessment results will be reported to the Project Manager. Major quality problems are reported to the Project Manager. Surveillance plans and results of the surveillances are provided to the Project Manager and Task Manager after a surveillance event.

Quality-related problems identified by project personnel must be reported to project management immediately for resolution. Any problems involving data quality, sample integrity, or test measurements will be thoroughly documented in an RDR form and/or a Problem and Discrepancies form and communicated to the appropriate Task Manager and Project Manager for resolution.

Significant quality-related problems that may affect customer satisfaction shall be communicated to the cognizant Product Line Manager by the Project Manager. 


\subsection{Records}

\subsection{Records Control}

The SBMS definitions of project records and record material apply to this project. As stated in the SBMS subject area, "Records Management” (PNNL 2005d), project records are any recorded information relating to a specific research project. Record material includes information, regardless of its media (e.g., hard copy, electronic, or microfilm), created or received in connection with PNWD business or research activities that documents research and administrative functions, policies, decisions, procedures, operations, or other activities, and is preserved for its value.

NOTE: E-mail that is record material must be printed and maintained as the record copy unless the e-mail is put directly into the PNNL Total Records Information Management (TRIM) System.

Record material that is not stored in field notebooks or LRBs (see Section 19.5) or is not electronic data gathered from sensors or instruments in the field and/or laboratory (see Section 14.3), such as project-specific field data forms, shall be scanned and managed as PDF files in accordance with Section 14.3. The record material shall be scanned and archived at least quarterly per year or more often, such as weekly or monthly, if the accumulation of the material is significant and inadvertent damage or loss would cause irreparable damage to the project.

Records that document the sampling subcontractor activities, analytical results, verification and compliance checks, quarterly and annual reports, test plans and associated results, groundwater monitoring plans, and assessment reports will be maintained as project records. Individual monitoring plans and work plans may identify other records requirements. Project records will be legible, identifiable, and maintained in accordance with the PNNL SBMS subject area, "Records Management" (PNNL 2005d). Test results documented in LRBs will be reviewed semi-annually by a technically qualified individual who did not perform the work. The reviewer will verify there is sufficient detail to retrace the investigation and confirm the results.

The project records specialist prepares and submits a Records Inventory and Disposition Schedule (RIDS) file index for review and approval by the records management representative and Quality Engineer. The records custodian reviews and updates the RIDS annually at a minimum, or when a major change to the program occurs. Records-retention schedules shall be based on requirements of the Tri-Party Agreement (Ecology et al. 1989), which requires the retention of records for 10 years after termination of the Tri-Party Agreement.

\subsection{Records Transfer to Storage}

On an annual basis, the records custodian will transfer to storage inactive records as identified by the project staff as not required for day-to-day operations. Sampling and analysis plans, assessments, and special project correspondences will be maintained by the project until the completion of the activity or project. The project records specialists generates the internal form (e.g., Records Transfer/Data Input [RTDI] form). The records management representative will sign the RTDI form as acknowledging 
receipt of the records and return a copy of this form to the records custodian. The RTDI form is then placed in project records.

Within 90 days of project completion or termination, records shall be transferred to storage and/or the client. The project records specialist completes the appropriate internal form (e.g., RTDI form). The records management representative will sign the RTDI form as acknowledging receipt of the records and return a copy of this form to the records custodian. The RTDI form is then placed in project records.

\subsection{Electronic Data/Records Management}

Electronic data gathered from sensors or instruments in the field and/or lab will be maintained and managed appropriately to allow for reproducible results. Electronic data that are directly delivered and/or used in analysis, or is delivered to the client, will be maintained as project records in accordance with the requirements of the SBMS subject area, “Records Management” (PNNL 2005c).

Electronic data produced by instrumentation or sensors are usually stored on that instrument and are only usable by the system itself. It is necessary for the electronic data to be transferred, without error, to a form that can be used by a variety of software applications. An example would be to transfer an ASCII file into a Microsoft Excel ${ }^{\circledR}$ file. ${ }^{1}$ To ensure the data-transfer process has occurred in an acceptable manner, a review of a representative sample of sufficient data points to provide confidence that the data have been transferred properly, shall occur. The review method used and results obtained shall be documented and retained as project records in the LRB, in accordance with Section 19.5. To retrieve the data, the staff member shall record the use of the data on the media used to store the raw data and in the project records. The staff member shall ensure unauthorized modifications are not made to the data during its use. The method of control shall be documented in the project records by the staff member. The staff member shall ensure a back-up of the data is maintained in the project records. Use of the data in software applications shall be documented, along with the software application name and version number.

Electronic data shall be archived and saved as project records based on the project's record retention period. When the project records are required to be maintained for a minimum of 10 years, after the close of the project, saving the raw electronic data files to a CD/DVD is sufficient. When the project's record retention requirements are longer than 10 years, the raw data files should be saved either to magnetic media (TRIM, tape) or optical media (CD/DVD). The Total Records Information Management (TRIM) system is one option for storing raw data files and is approved for projects that have a permanent retention period.

Backup and archive processes shall be followed for maintaining the data during the life of the project. Electronic data backups shall be performed nightly, in accordance with the requirements identified by the PNNL IT Computing Services - InfoSource website. The computer-backup procedures identified in the PNNL InfoSource website for Data Backup Options shall be followed based on the type of computer or server on which the data are stored. The data-backup process is identified in the following sections.

\footnotetext{
${ }^{1}$ Microsoft Excel is a registered trademark of Microsoft Corporation.
} 


\subsubsection{Workstations}

PNNL staff are responsible for assuring the data on their computers are regularly backed up. There are three options for backing up these data:

1. The staff member can sign up for one of the PNNL workstation backup and restore (WBR) services: WBR Connected DataProtector for Windows ${ }^{\circledR}$, WBR Mac for Macintosh ${ }^{\circledR}$, or WBR Networker for all other systems. ${ }^{2,3}$ WBR is free to each PNNL staff member for one workstation. Additional backup subscriptions are available for a small monthly fee. (See the WBR website for restore instructions.) The maximum backup size is 100 gigabytes (GB) for Windows workstations.

2. A network shared folder may be used to store files on a PNNL network file server. Network shared folders are backed up nightly. To retrieve files from a backup, request a file restore by calling the PNNL Help Desk at 375-6789 or send an e-mail. They will need the complete name of the shared folder (e.g., IIpnl10 \projects) and the name and date of the file or directory that needs to be restored.

3. Manually copy files to floppy disks, CDs, or DVDs. Most computers purchased through the Managed Hardware Program (MHP) come with large-capacity floppy drives, CD-RW drives, and/or DVD drives. A CD can hold 600 megabytes or more; DVDs 4.7 GB. Either of these methods is suitable for backing up important data files, but not recommended for backing up the entire system.

\subsubsection{Servers}

The data backup options for servers include:

1. The Workstation Backup and Restore (WBR) service. For a small monthly fee, WBR performs a full backup of all the project's programs and data. (See the WBR website for restore instructions.)

2. Backing up to Zip disks or to a tape drive connected to the server. If a tape drive connected to the project server is used, refer to the manufacturer's instructions for establishing backup schedules and performing restores.

Data archiving shall occur at least every 2 weeks. It is recommended archiving occur at least once a week. The electronic data shall be archived to a CD/DVD and kept in the project working files until the electronic data are no longer being used; then, the electronic data shall be moved to TRIM when longer storage retention is required by the records requirements.

\subsection{Procurement Control}

Quality-affecting materials (e.g., calibration standards and chemicals) or services (e.g., calibration, analytical services, or other subcontracts for technical services) will be obtained in accordance with the SBMS subject area, "Purchasing Goods and Services” (PNNL 2007e). For this project, the majority of procurements will result in purchases of services such as drilling, sampling, and analytical services. All procurements will be obtained in accordance with the SBMS subject area, "Purchasing Goods and

\footnotetext{
${ }^{2}$ Windows is a registered trademark of Microsoft Corporation.

${ }^{3}$ Macintosh is a registered trademark of Apple, Inc.
} 
Services" (PNNL 2007e). SOWs for purchasing services shall be reviewed and signed by the project Quality Engineer to assure consistency of QA requirements specified to subcontractors with project quality standards in this QAPjP.

\subsection{Groundwater Sampling}

If groundwater samples are collected by other than the EM-20 Roadmap Project participants, requirements of the EPA Requirements for Quality Assurance Project Plans (EPA QA/R-5) (EPA/240/B-01/003) and HASQARD (DOE/RL-96-68) will be passed on to subcontractors as appropriate. A review of the SOW must be performed by the Quality Engineer during the planning stages and preparation.

\subsection{Groundwater and/or Sediment Analytical Measurements}

If groundwater or sediment analysis will be conducted by subcontractors or collaborators on the project, requirements will be specified in the SOW or Letter of Instruction (LOI) as applicable, and shall be used to obtain the analytical services. The LOI is the mechanism to be used for work requests to other Hanford Site contractors. An LOI or SOW must accompany each purchase order. A review must be performed by the Quality Engineer during the planning stages and preparation of the SOW or LOI. The SOW must define the data quality and any additional project requirements associated with the service requested. The data quality requirements should include a description of the QC samples for each analysis for determining the level of possible contamination from preparation and analysis. The project requirements should include information on analysis method, calibration standards traceable to the National Institute of Standards and Technology, sample turnaround time and reporting requirements, and disposal requirements for remaining sample material and the waste from the process. The LOI or SOW will include the requirements in the EPA Requirements for Quality Assurance Project Plans (EPA QA/R-5) (EPA/240/B-01/003) and HASQARD (DOE/RL-96-68) to the analyst.

\subsection{Other Hanford Contractor Services}

Other Hanford contractor services (e.g., well drilling and construction) will be obtained using the procurement process. An electronic requisition will be generated by project staff accompanied by a work authorization document (LOI or SOW). The work authorization document will describe the requirements for the requested services. The SOW will pass on the requirements of the EPA Requirements for Quality Assurance Project Plans (EPA QA/R-5) (EPA/240/B-01/003) and HASQARD (DOE/RL-96-68) to the subcontractor. A review must be performed by the Quality Engineer during the planning stages and preparation of the SOW or LOI.

\subsection{Staff Training}

Staff performing activities affecting quality shall be issued documented training assignments including applicable project administrative and technical procedures and this QAPjP.

1. Project Manager and staff members will assess project-specific training needs. The assessment will include evaluating cumulative training records of the staff. 
2. Project Manager will assign reading and/or briefings of procedures as needed. If training is assessed and the need for formalized training is identified, the staff member will be scheduled to attend a formal training class.

3. Training will be documented on either a Briefing Document, or an individual On-the-Job Training (OJT) or Reading Assignment Documentation form, or a Group OJT or Reading Assignment Documentation form. These forms are available internally to PNNL staff. Documentation shall be sent to the PNNL Laboratory Training Coordinator for input into the training database. The training database will contain the record copy of project staff training.

Project staff shall be comprised of personnel who are knowledgeable and possess adequate technical, managerial, or professional skills to perform all assigned tasks. The Project Manager will identify any additional specific project-related processes that will require project-staff training and qualification and who will be responsible for assuring the project-specific training will be developed, delivered, and changes managed in accordance with the SBMS subject area, "Training Design, Development, Implementation and Evaluation” (PNNL 2002a). The project shall maintain training documentation for project-required coursework or OJT taken by staff that is not capable of being tracked in the Laboratory's training database in accordance with the SBMS subject area, "Training and Qualification for Staff and Non-Staff” (PNNL 2005e).

The Project Manager or delegate shall inform the immediate manager of project staff of the requirement to take project-required training, and confirm the training has been completed prior to project staff conducting work that requires the training. The immediate manager of project staff, or their delegate, shall record the need for identified project-required training and assuring training (and retraining for changes) records (for both Laboratory-level and project-specific training) will be maintained in accordance with the SBMS subject area, "Training and Qualification for Staff and Non-Staff” (PNNL 2005e).

The development of software products that require complex or unfamiliar interactions with users and operators should include a comprehensive plan for training. The training plan should include the following:

a. A description of the populations to be trained, the training objectives for each population, and the content to be covered in the training

b. An estimate of the amount of resources necessary for training development, delivery, and time expenditures

c. Procedures for evaluating the effectiveness of the training and for making modifications to the training.

The Project Manager has identified the following project-specific training requirements for project core team members:

- PMP

- QAPjP

- Health and Safety Plan. 
The project shall maintain training documentation for project-required coursework or OJT taken by staff that cannot be tracked in the Laboratory's training database in accordance with the SBMS subject area, “Training and Qualification for Staff and Non-Staff” (PNNL 2005e).

\subsection{Software Control}

Various project tasks require the use of databases and software that may be managed, controlled, and operated by entities external to PNNL. The project also requires the use of databases and software that are developed, managed, controlled and operated by PNNL. A graded approach is used to establish software quality assurance requirements based on identified risk. Software QA at PNNL is based on DOE O 414.1C, Quality Assurance. This order establishes specific requirements for software related to safety and nuclear facilities.

The project uses databases, custom applications, and configurable software to support various activities. These databases, custom applications, and configurable software (spreadsheets, and queries) used to generate reportable results shall be documented in accordance with the SBMS subject areas, Safety Software (PNNL 2007f) or Software (PNNL 2007h). This documentation is maintained in project files.

\subsection{Software and Software Applications}

"Software" is defined as computer programs-including computer programs embedded in firmware (see the SBMS subject areas, "Safety Software" [PNNL 2007f] or "Software" [PNNL 2007h]). Software that is an integral part of firmware or equipment, where all software maintenance is performed by the vendor and the software is verified as an integral part of the system (e.g., calibration with known standard materials), is excluded. Any vendor will be required to follow the NQA-1-2000 standards for software when the software that is part of firmware is identified as safety software. The safety software clause (QA-197a) will be passed down in any SOWs at a minimum, and possibly with additional clarification when requested by the vendor when the work being done is identified as safety software. The software clause (QA-197b) will be passed down in any SOWs at a minimum, and possibly with additional clarification when requested by the vendor for non-safety applications being developed.

All software applications used for the projects under this QAPjP will be reviewed and identified as safety software or software when the results from the software applications are part of a deliverable to the client. The grading process for safety software will be recorded and copies for each application will be maintained as project records for each project that falls under this QAPjP. Software applications that will follow this plan have the potential to be identified as safety software and when graded as such, will follow the Safety Software (PNNL 2007f) Level C requirements, at a minimum as identified in SBMS. The SBMS subject area, "Safety Software" (PNNL 2007h) is based on DOE O 414.1C, which includes the NQA-1-2000 standard.

If applications are not identified as safety software, they will be documented as software and the documentation will be maintained as project records. Safety Software and software applications identified for the projects in this QAPjP will perform the work activities identified below that pertain to custom developed, configurable, acquired/legacy, utility calculations and commercial design and analysis software. 
All safety software applications are required to be identified in the Information Resource Inventory (IRI). All safety software will be identified as safety system software, safety and hazard analysis software and design software, or safety management and administrative controls software. Additionally, the following will be identified for each software application in the IRI: type of software, graded level, software version, and software scope, tailored for the intended use with the project. The owner and point of contact information will also be identified in the IRI.

\subsubsection{Minimum Documentation Requirements}

To ensure the implementation of the software satisfies requirements, the following documentation is required as a minimum for all Safety Software applications. These document requirements must be reviewed and approved for software code being developed as a deliverable. The rigor of the documentation will be decided based on the grading of the safety software application. Refer to the SQA Activity Tailoring exhibit in the SBMS subject area, "Safety Software" (PNNL 2007f) for guidance on the rigor needed for the documentation requirements. The document requirements will be for each document identified below. The document requirements may be grouped together in one document or may be separated into separate documents identified below:
a. Software Requirements Specifications (SRS)
b. Software Design Description (SDD)
c. Verification and Validation Plan (VVP)
d. Verification and Validation Report (VVR)
e. Configuration Management Plan (CMP)

1. A problem reporting and corrective action tracking system will be identified with the CMP documentation.

2. Data management process will also be identified, when applicable

f. Procurement contractual documentation, when applicable.

\subsubsection{Software Requirements Specification}

The software requirements specification (SRS) shall clearly and precisely describe each of the essential requirements (functions, performances, design constraints, and attributes) of the software and external interfaces. Each requirement shall be defined such that its achievement is capable of being objectively verified and validated by a prescribed method (for example: inspection, analysis, demonstration, or test).

The SRS is subject to the Software Requirements Review (SRR), identified in applicable configuration management plans when needed, which identifies the quality assurance aspects of work activities.

\subsubsection{Software Design Description}

The software design document (SDD) shall depict how the software will be structured to satisfy the requirements in the SRS. The design document shall describe the components and subcomponents of the 
software design, including databases and internal interfaces, and is a technical description of how the software will meet the requirements established in the requirements specification. Its most important function is to describe a decomposition of the whole system into components (subsystems, segments, etc.) that are complete and well-bounded. In addition, it should document the rationale for the more important design decisions to facilitate the understanding of the system structure.

The SDD will document major system features such as databases, diagnostics, external and internal interfaces, as well as the overall design structure. It involves descriptions of the operating environment, timing, system throughput, tables, sizing, centralized or distributed processing, extent of parallelism, client/server, reusable objects library, program design language, prototypes, modeling, simulation, etc. The design description will also document any input and output data that may be required. The QA organizational element can observe demonstrations, which is a more efficient way to review and assess written design documentation.

The software design description will be updated after each significant review. A new version containing a more detailed design description is developed for each subsequent review.

\subsubsection{Verification and Validation Plan}

The verification and validation plan (VVP) shall identify and describe the methods (for example, inspection, analysis, demonstration, or test) to be used:

1. To verify the following:

- Requirements in the software requirements specifications have been approved by staff with appropriate authority

- $\quad$ Requirements in the requirements specifications are implemented as described in the software design description

- Design documented in the software design description is implemented in the code.

2. To validate that the code, when executed, complies with the requirements expressed in the requirements specification.

The VVP describes the overall approach for verification and validation of the software or modeling approach and will be produced and reviewed incrementally, for safety software applications. The tasks, methods, and criteria for verification and validation will be described in the appropriate verification and validation plans for each application.

The VVP will be used for documentation of the testing standards and practices as they are defined in the plan for each application. The VVP will document the scope of the validation testing to ensure the baseline requirements and explain the stages of development that require customer review and the extent of the verification that will precede such a review.

The VVP will specify minimum test documentation requirements for each test performed. Additionally, a section of each plan will identify a verification matrix where the requirements are listed with its corresponding test. A matrix will be maintained during the life of the software and will be used to verify all the requirements have been met, identified, and tested. 
The contents of the VVP will be evaluated at a VVP review prior to testing. Such a review will be conducted when significant changes are made to the baseline. The VVP review will be used to identify all changes to be tested and to pass on pertinent information to the appropriate testing staff.

\subsubsection{Verification and Validation Report}

The verification and validation report (VVR) shall describe the results of the execution of the VVP review. The report summarizes the observed status of the software as a result of the execution of the VVP. The report should include the following information:

a. Summary of all life cycle verification and validation tasks

b. Summary of task results

c. Summary of anomalies and resolutions

d. Assessment of overall software quality

e. Summary from the verification matrix

f. Recommendations such as whether the software is, or is not, ready for operational use.

The report may be a full report or a summary (depending upon the grading of the software).

\subsubsection{User Documentation}

User documentation will be developed for applications where the code is part of the deliverable.

\subsubsection{Configuration Management Plan}

The Configuration Management Plan (CMP) shall document methods to be used for identifying software items, controlling and implementing changes, and recording and reporting change implementation status. The CMP should describe the tasks, methodology, and tools required to assure that adequate configuration management procedures and controls are documented and are being implemented correctly. If the CMP is not a standalone document, and is included in the QAPjP or PMP, it is not necessary that the QA organizational element prepare it; however, it is essential that one exist for each project or set of applications under each project.

The CMP should describe the methods to be used for the following:

a. Identifying all the configuration items (each software item will be identified if it is considered to be safety software or not; if identified as safety software, the level will be identified as well)

b. Controlling and implementing changes

c. Recording and reporting change and problem reports implementation status

d. Conducting configuration audits

e. Identifying review and approval cycles, as well as signature authority

f. Identifying the personnel responsible for maintaining the baselines and distributing the plan. 
The CMP shall contain the information identified in the SBMS subject area, "Safety Software" (PNNL 2007f) for the appropriate level of software to which the application was graded. Most software application for the work under this project will be graded at Level C.

\subsection{Software Use in Analysis}

The use of software of any kind to conduct analyses delivered, or in support of a deliverable, to the customer includes data analysis tools such as spreadsheets and statistical analysis software, databases, modeling and simulation tools. Excluded are software productivity tools such as word processors and spreadsheets when no automated calculations, macros, or scripts are used. The projects under this QAPjP shall conduct work in accordance with requirements for the control of software used in analyses as defined in the SBMS subject area, "Safety Software" (PNNL 2007f) or "Software” (PNNL 2007g) based on how the software being used is graded.

\subsection{Utility Calculations}

The purpose of this section is to define a uniform method for documenting the quality controls in place when using software packages (e.g., Microsoft Excel ${ }^{\circledR}$, Mathematica ${ }^{\circledR}$, Matlab ${ }^{\circledR}$, Mathcad ${ }^{\circledR}$, etc. known as Utility Calculations) for calculations that are a significant part of a client deliverable, but not classified as safety software. ${ }^{4,5,6}$ As stated above, the safety software classification involves software failure that could result in the loss of life or serious injury, exposure to hazardous materials in excess of standards, serious damage to the environment, or noncompliance with laws or regulations.

Excel or other Utility Calculation analyses that are not used for a significant part of a client deliverable, or are only used as a double check, are exempt from these instructions. These instructions apply to the use of scripts and/or macros, within Excel, as well as Excel basic calculations. Portions of this project that have been identified as containing safety software must follow the Utility Calculations Guidance identified in the SBMS subject area, "Safety Software." For additional information, refer to the SBMS subject area, "Software," "Section 11 - Using Software to Conduct Analysis."

NOTE: Excel is used as the example in these instructions; however, the process is the same for all other utility calculations.

These requirements and instructions apply to Project Managers and staff who will use Excel to conduct analysis to be delivered to the client, or to conduct analyses in support of a deliverable to the client. The process shall be implemented as follows:

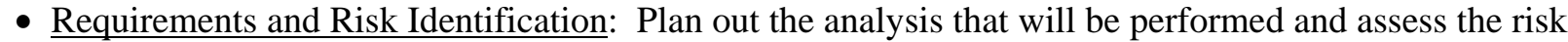
associated with the failure of the software. Document the associated risk and the analysis to be performed (this could be one paragraph in a Microsoft Word ${ }^{\circledR 7}$ document or on another tab in the Excel spreadsheet itself). (See risk examples in Table 17.1.)

\footnotetext{
${ }^{4}$ Mathematica is a registered trademark of Wolfram Research, Inc.

${ }^{5}$ Mathcad is a registered trademark of Parametric Technology Corporation

${ }^{6}$ Matlab is a registered trademark of The MathWorks, Inc.

${ }^{7}$ Microsoft Word is a registered trademark of the Microsoft Corporation.
} 
Table 17.1. Software Risk Management Examples

\begin{tabular}{|c|c|c|c|c|c|}
\hline Identified Risk & $\begin{array}{c}\text { Overall Risk } \\
\text { to Project }\end{array}$ & Preventive Action & $\begin{array}{c}\text { Contingency } \\
\text { Action }\end{array}$ & Trigger & Owner \\
\hline $\begin{array}{l}\text { Change in } \\
\text { requirements after } \\
\text { start of design/ } \\
\text { development }\end{array}$ & Medium & $\begin{array}{l}\text { Have customer } \\
\text { approve requirements } \\
\text { before design/ } \\
\text { development, flexible } \\
\text { design and CM process }\end{array}$ & $\begin{array}{l}\text { Changes affect } \\
\text { either schedule or } \\
\text { resource allocation }\end{array}$ & $\begin{array}{l}\text { Customer } \\
\text { request }\end{array}$ & $\begin{array}{l}\text { Battelle / } \\
\text { Customer }\end{array}$ \\
\hline $\begin{array}{l}\text { Incomplete input } \\
\text { data }\end{array}$ & High & $\begin{array}{l}\text { Identify appropriate } \\
\text { sources of validation } \\
\text { data }\end{array}$ & $\begin{array}{l}\text { Manual updates to } \\
\text { input tables are } \\
\text { tracked through the } \\
\text { change control } \\
\text { process }\end{array}$ & $\begin{array}{l}\text { Appropriate } \\
\text { input tables } \\
\text { not available }\end{array}$ & $\begin{array}{l}\text { Battelle / } \\
\text { Customer }\end{array}$ \\
\hline $\begin{array}{l}\text { Change in project } \\
\text { budget or/or } \\
\text { schedule }\end{array}$ & Low & $\begin{array}{l}\text { Define and implement } \\
\text { new process }\end{array}$ & $\begin{array}{l}\text { Continue current } \\
\text { process }\end{array}$ & $\begin{array}{l}\text { Coordination } \\
\text { issues with } \\
\text { customer } \\
\end{array}$ & $\begin{array}{l}\text { Battelle / } \\
\text { Customer }\end{array}$ \\
\hline $\begin{array}{l}\text { Invalid regulatory } \\
\text { products that rely } \\
\text { on calculations } \\
\text { performed with } \\
\text { this software }\end{array}$ & Low & $\begin{array}{l}\text { Development and } \\
\text { execution of a } \\
\text { Software Test Plan to } \\
\text { cover all calculations } \\
\text { in the system }\end{array}$ & $\begin{array}{l}\text { Identify critical } \\
\text { calculations and } \\
\text { test based on use of } \\
\text { the system }\end{array}$ & $\begin{array}{l}\text { Software } \\
\text { codes are } \\
\text { required to be } \\
\text { reviewed with } \\
\text { a customer } \\
\text { QA/QC } \\
\text { process }\end{array}$ & Customer \\
\hline
\end{tabular}

- Design and Validation Planning: Prepare and document how the Excel file will be validated/reviewed and tested by an independent technical reviewer. Identify and document who will perform the independent technical review. (Identify what the problem is that is trying to be solved and what actual calculations are being performed to solve the problem. This information will be useful for the independent technical reviewer. This could be one paragraph in a Microsoft Word document or on another tab in the Excel spreadsheet.)

- Implementation: Conduct the analysis using the Excel spreadsheet with the appropriate calculations based on the planning previously performed. (If the implementation of the analysis has changed, go back and update the risk associated with the analysis and the documentation to be used for the validation, if applicable.)

- Verification: Review/verify the results of the analysis. Review the results produced from the analysis. Determine if the analysis and results support the problem that is trying to be solved. Document the verification/review step. (Documenting this step can be done with one paragraph, in a Word document or on another tab in the Excel spreadsheet itself, of what was reviewed and identify if the outcome was acceptable or if additional work needs to be done.)

- Validation: Conduct independent review of results and validation. Provide the identified independent technical reviewer the Excel spreadsheet and Word document, if applicable. (The reviewer needs to have all the information regarding the requirements, risk, design and review expectations to perform the review.) 
- Independent Technical Review: Reviewer performs the review, per the instructions provided, and documents any additional checks performed on the file that extended outside the original scope of the review and the method used to perform the review of the results. The reviewer documents the outcome of the review. (The documentation can be one paragraph in a Word document or on another tab in the Excel spreadsheet itself.)

- The results shall be determined based on using an alternate method to perform the analysis. Typical alternate methods include: literature review, empirical data, hand-calculations, executing the analysis on a comparable but different tool.

- Documentation: Print the Excel spreadsheet with the analysis/results and attach the Word document or the tab in the Excel spreadsheet itself that contains the identified requirements, risk, design, validation steps, verification and independent technical review steps and results. Have the independent technical reviewer sign the document. The verifier needs to sign the verification step. Place this signed document in project records.

\subsection{Nonconformances and Deficiencies}

Procured materials found to be in nonconformance with specifications or where the quality of an activity is found not to be in compliance, the quality problem will be documented in the Action Tracking System (ATS) in accordance with the SBMS subject area, “Quality Problem Reporting” (PNNL 2005c). Corrective actions are documented in ATS in accordance with the SBMS subject area, "Assessment Management” (PNNL 2005a).

If a deficiency is found where a procedure or process is not followed or the activity is not in compliance with a procedure or process, the deficiency will be documented into the ATS in accordance with the SBMS subject area, “Quality Problem Reporting” (PNNL 2005c). Corrective action will be documented using ATS in accordance with the SBMS subject area, “Assessment Management” (PNNL 2005a).

When the analytical data (hard copy or electronic data) are found to be incomplete or deficient in data by the data processing staff verification, a Problem and Discrepancies form is filled out in accordance with the PNNL internal procedure DM-3, Verification of Analytical Data. When the technical staff complete the initial data review and/or a comparison of the recent data to historical trends, any suspect data are submitted to the verification group on an RDR form in accordance with the project internal procedure DA-3, Data Review Procedure. If there are any limitations noted on the data, a flag will be added to the data in HEIS.

Subcontractors will be required to have a system to identify and disposition nonconforming items, procedure deficiencies, processes not followed, or activities not in compliance to a procedure or a process. This requirement will be specified in a SOW. 


\subsection{Document Control}

\subsection{Project Quality Assurance Plan Control}

Distribution and control of this QAPjP shall be performed in accordance with the SBMS subject area, “Publishing Scientific and Technical Information” (PNNL 2007d). Modifications to this QAPjP shall be made either by revision or by issuing an Interim Change Notice (ICN). See Figure 19.1 for the ICN form and instructions. This plan will be revised after four ICNs or a major change in project scope or requirements. Any PNNL staff member may request a change to this QAPjP by submitting the requested change in writing to the Project Manager and Quality Engineer. All reviewers listed on the signature page and affected by the change will approve the revision. The ICN will be placed in front of the signature page, and the individual pages will be inserted, or the necessary correction will be lined out and the correction added with the appropriate initials and date. The QAPjP will be reviewed at least annually unless a different review cycle is documented.

\subsection{Technical Procedure Control}

Technical procedures referenced by this QAPjP and used by PNNL staff will be contained in a PNNL internal procedure manual, or other procedure manual, as appropriate. Technical procedures will be distributed and controlled in accordance with the SBMS subject area, "Document Control” (PNNL 2006a). Modifications to any of the internal procedures shall be made either by revision or issuance of an ICN.

Procedures will be revised after two (2) major ICNs, or if the procedure format has changed. Any PNNL staff member may request a change to procedures at any time by submitting the requested change in writing to the author. The author, technical reviewer, Task Manager, and project Quality Engineer will review and approve the ICN. The Project Manager may delegate his/her review and approval authority. The ICN will be placed in front of the signature page and the individual pages will be inserted or the necessary correction will be lined out and correction added with initial and date. Contact the project Quality Engineer for the electronic copy of the ICN. New or revised technical procedures, whether they will be included in the internal procedures manual or not, must be developed in accordance with the SBMS subject area, "Procedures, Permits, and Other Work Instructions" (PNNL 2004). The procedure owner is required to review the procedure at least every 2 years.

\subsection{Administrative Procedure/Instruction Preparation and Control}

Administrative procedures/instructions used by PNNL staff will be developed, approved, and controlled to ensure consistent application by those staff performing the defined task(s). These procedures/instructions will be developed, approved, and controlled in a manner that has been approved by the appropriate Project Manager and Quality Engineer. 


\section{HEADER:}

\section{INSTRUCTIONS FOR ICN FORM}

The ICN number is identified as ICN No.-

For a published document, each page of the ICN shall have a header on the right upper-corner that includes the report number, the date and the pagination. The number of the ICN must be placed after the PNNL number. The second line of the header should show the date and pagination. The cover sheet needs to identify how many pages in the ICN packet.

Example header: $\quad$ PNNL-Xxxxx-ICN-X

Month, day, year; Page $\mathrm{x}$ of $\mathrm{xx}$

\section{SECTION A.}

Self-explanatory.

\section{SECTION B.}

Include all actions that the document holder must take to update the procedure or instruction. Possible actions include: replacing pages of the document with pages that are distributed with the ICN and marking up the document (in ink) to reflect the changes identified on the ICN, or attach the ICN cover sheet to the front of the document. For a "Published" groundwater monitoring plan, include the following statement: "Attach this ICN to the front of the document, just before the title page.”

\section{SECTION C.}

Identify, by title, all personnel whose job functions will be affected by the change and include a brief description of the effect. If there is no effect on personnel (e.g., the change was made to clarify the intent of the procedure or to correct a typographical error), this block should be marked "N/A."

\section{SECTION D.}

State the reason for the change followed by a description of the change (including the affected paragraph, information which is deleted, and the actual wording of any replacement test) for each change included on the ICN.

\section{SECTION E.}

The Cognizant Manager shall document the reason for not obtaining original reviewers approval and/or any other decisions that must be documented. Additionally, list the individuals who will receive the document (distribution list).

\section{SECTION F.}

Identify type of change and document required approvals.

Figure 19.1. Interim Change Notice (Page 1 of 2) 
INTERIM CHANGE NOTICE (ICN)

\begin{tabular}{|c|c|}
\hline $\begin{array}{l}\text { A. Document No.: } \\
\text { Revision No.: } \\
\text { Document Title: } \\
\text { Document's Original Author: }\end{array}$ & $\begin{array}{l}\text { Implementation } \\
\text { Date of ICN: } \quad, \quad \text {, }\end{array}$ \\
\hline & Change Requested By: \\
\hline \multicolumn{2}{|l|}{ B. Action: } \\
\hline \multicolumn{2}{|l|}{ C. Effect of Change: } \\
\hline \multicolumn{2}{|l|}{ D. Reason for Change/Description of Change: } \\
\hline \multicolumn{2}{|l|}{ Reason for Change: } \\
\hline \multicolumn{2}{|l|}{ Description of Change: } \\
\hline \multicolumn{2}{|l|}{ E. Document Management Decisions: } \\
\hline \multirow[t]{2}{*}{ F. Task Manager Approval Signatures (Please Sign and Date) } & Type of Change (Check one): \\
\hline & _ Minor \\
\hline
\end{tabular}

Project Quality Engineer Approval:

Date:

Author Approval: Date:

Other Approvals: Date:

Figure 19.1. Interim Change Notice (Page 2 of 2) 


\subsection{Test Plans and Other Work Documents}

Test plans and other work instructions used by PNNL staff will be developed, approved, and controlled to ensure consistent application by those staff performing the defined task(s). These procedures/instructions will be developed, approved, and controlled in a manner that has been approved by the appropriate Project Manager and Quality Engineer. Distribution and control of test plans and other plans shall be performed in accordance with the SBMS subject area, "Publishing Scientific and Technical Information" (PNNL 2007d).

\subsection{Field Notebooks and Laboratory Record Books}

Field notebooks and LRBs used by PNNL EM-20 Roadmap Project staff will be managed, controlled, and reviewed in accordance with the SBMS subject area, "Laboratory Record Books" (PNNL 2000). In particular, the Project Manager shall ensure that all LRBs are reviewed at least twice per year. The reviewer, a qualified individual, confirms that there is sufficient detail to trace the investigation and confirm the test results or repeat the investigation and achieve comparable results, without recourse to the original investigator.

Non-PNNL EM-20 Roadmap Project staff, such as subcontractors and/or collaborators shall comply with the following procedural steps regarding laboratory records books, or an EM-20 Roadmap Projectapproved equivalent:

1. Use LRBs with beige-colored binding.

2. The initial LRB custodian shall complete the title, author, and period covered sections of the information block (first sheet inside the cover). If the LRB is transferred, the new custodian shall enter their name, payroll number, location, and date received to the lower portion of the information block.

3. If persons other than the custodian make entries, the custodian shall list above or below the information block on the first sheet inside the cover, the names of those persons and obtain sample signature and initials from each.

4. Use the following procedure as new project number and project or activities are initiated.

- $\quad$ Record the starting page, the project or activity title in the table of contents.

- $\quad$ Record as the first entry the research activity title, the project or work authorization number, and a brief description of the objectives and planned approach.

- Record observations/data chronologically. Describe (narrative or sketch) experimental apparatus, equipment, and any procedures, data sheets, etc., that are used.

5. Date and sign each page. List person(s) who performed the work.

6. Record information only in permanent ink, line out unused portions of pages, and keep pages intact.

7. Do not erase or obliterate entries. Mark out errors or corrections with single lines. Initial and date all changes other than editorial corrections. If the change is substantive, record the reason for it.

8. Use the following steps if it is necessary to attach a loose sheet. 
a. Attach the sheet to an unused page of the LRB by tape or glue.

b. Write the LRB and page numbers on the attached sheet (in case it comes loose).

c. Make an entry in the LRB to introduce or describe the attached sheet.

9. Maintain a list in the project or activity file identifying the LRB numbers, custodians, and locations.

10. Record as the last entry for a project or activity a statement noting completion of the work or, if appropriate, reference to a subsequent LRB.

11. Store LRBs in metal file cabinets or receptacles that prevent physical damage or access by unauthorized persons when not in use, and allow easy retrieval for periodic inventory.

12. Notify the EM-20 Roadmap Project Document Control in writing when LRBs are reassigned.

13. Return LRBs to the EM-20 Roadmap Project Document Control when complete or at project end. Users may copy appropriate pages for their personal files and future reference. If the staff member for future reference retains the LRBs, they must be protected from physical damage or access by unauthorized persons and made available for periodic inventory.

14. Return LRBs to Document Control or request reassignment when the custodian terminates employment.

15. Make copies of LRBs, or applicable pages, for inclusion in project files, when appropriate.

\subsection{References}

10 CFR 830, Subpart A- “Quality Assurance Requirements.” U.S. Code of Federal Regulations.

40 CFR 136, Chapter 1, Appendix B (7/1/01). U.S. Environmental Protection Agency. “Guidelines

Establishing Test Procedures for the Analysis of Pollutants.” U.S. Code of Federal Regulations.

Atomic Energy Act. 1954, as amended, Ch. 1073, 68 Stat. 919, 42 USC 2011 et seq.

CAWSRP - Conducting Analytical Work in Support of Regulatory Programs. 2006. Pacific Northwest National Laboratory. Available online at http://etd.pnl.gov/docs/conducting-work/index.stm

CERCLA - Comprehensive Environmental Response, Compensation, and Liability Act. 1980. Public Law 96-150, as amended, 94 Stat. 2767, 42 USC 9601 et seq.

DOE Order 414.1C. 2005, as amended. Quality Assurance. U.S. Department of Energy, Washington, D.C.

DOE Order 435.1. 2001, as amended. Radioactive Waste Management. U.S. Department of Energy, Washington, D.C.

DOE Order 450.1. 2003, as amended. Environmental Management System. U.S. Department of Energy, Washington, D.C. 
DOE Order 5400.5. 1993, as amended. Radiation Protection of the Public and the Environment. U.S. Department of Energy, Washington, D.C.

DOE/RL-96-68. 1998. Hanford Analytical Services Quality Assurance Requirements Documents. HASQARD, Volumes 1, 2, 3, and 4. U.S. Department of Energy, Richland Operations Office, Richland, Washington.

Ecology - Washington State Department of Ecology, U.S. Environmental Protection Agency, and U.S. Department of Energy. 1989, as amended. Hanford Federal Facility Agreement and Consent Order. Document No. 89-10 (The Tri-Party Agreement), Olympia, Washington.

EMSL-LV-0539-17. 1979. Radiochemical Analytical Procedures for Analysis of Environmental Samples. U.S. Environmental Protection Agency, Las Vegas, Nevada.

EPA/240/B-01/003. 2001. EPA Requirements for Quality Assurance Project Plans (EPA QA/R-5). U.S. Environmental Protection Agency, Washington, D.C.

EPA/240/B-06/001. 2006. Guidance on Systematic Planning Using the Data Quality Objectives Process (EPA QA/G-4). U.S. Environmental Protection Agency, Washington, D.C.

EPA-600/4-79/019. 1979. Handbook for Analytical Quality Control in Water and Wastewater Laboratories. U.S. Environmental Protection Agency, Cincinnati, Ohio.

EPA-600/4-79-020. 1983. Methods for Chemical Analysis of Water and Wastes. U.S. Environmental Protection Agency, Washington, D.C.

EPA-600/4-80-032. 1980. Prescribed Procedures for Measurement of Radioactivity in Drinking Water. U.S. Environmental Protection Agency, Cincinnati, Ohio.

EPA-600/4-88-039. 1988. Methods for the Determination of Organic Compounds in Drinking Water. U.S. Environmental Protection Agency, Washington, D.C.

EPA/600/R-96/055. 2000. Guidance for the Data Quality Objectives Process (QA/G-4), U.S. Environmental Protection Agency, Washington, D.C.

EPA-R4-73-014. 1973. Procedures for Radiochemical Analysis of Nuclear Reactor Aqueous Solutions. U.S. Environmental Protection Agency, Cincinnati, Ohio.

EPA/SW-846. 1986, as amended. Test Methods for Evaluating Solid Waste: Physical/Chemical Methods, SW-846, Third Edition. Office of Solid Waste and Emergency Response, U.S. Environmental Protection Agency, Washington, D.C. Available online at http://www.epa.gov/epaoswer/hazwaste/test/main.htm

National Water Well Association. 1986. RCRA Ground Water Monitoring Technical Enforcement Guidance Document. Dublin, Ohio.

NQA-1-2000. 2001. Quality Assurance Requirements for Nuclear Facility Applications. The American Society of Mechanical Engineers, New York, New York. 
PAAA-Price-Anderson Amendments Act. Energy Policy Act of 2005. Title VI—Nuclear Matters, Subtitle A-Price-Anderson Act Amendments, Section 601 et. seq. Public Law 109-58, as amended. 42 USC 15801 et seq.

PNL-MA-567. 1993, as amended. Procedures for Ground-Water Investigations. Pacific Northwest National Laboratory, Richland, Washington.

PNL-MA-580. 2004, as amended. Surface Environmental Surveillance Procedures Manual, Revision 4. Pacific Northwest National Laboratory, Richland, Washington.

PNNL. 2000. Laboratory Record Books. Standards-Based Management System, Pacific Northwest National Laboratory, Richland, Washington. Available online at http://sbms.pnl.gov/standard/2l/2100t010.htm

PNNL. 2002a. Training Design, Development, Implementation and Evaluation. Standards-Based Management System, Pacific Northwest National Laboratory, Richland, Washington. Available online at http://sbms.pnl.gov/standard/1f/1f00t010.htm

PNNL. 2004. Procedures, Permits, and Other Work Instructions. Standards-Based Management System, Pacific Northwest National Laboratory, Richland, Washington. Available online at http://sbms.pnl.gov/standard/74/7400t010.htm

PNNL. 2005a. Assessment Management. Standards-Based Management System, Pacific Northwest National Laboratory, Richland, Washington. Available online at http://sbms.pnl.gov/standard/4i/4i00t010.htm

PNNL. 2005b. Calibration. Standards-Based Management System, Pacific Northwest National Laboratory, Richland, Washington. Available online at http://sbms.pnl.gov/standard/79/7900t010.htm

PNNL. 2005c. Quality Problems Reporting. Standards-Based Management System, Pacific Northwest National Laboratory, Richland, Washington. Available online at http://sbms.pnl.gov/standard/78/7800t010.htm

PNNL. 2005d. Records Management. Standards-Based Management System, Pacific Northwest National Laboratory, Richland, Washington. Available online at http://sbms.pnl.gov/standard/1a/1a00t010.htm

PNNL. 2005e. Training and Qualification for Staff and Non-Staff. Standards-Based Management System, Pacific Northwest National Laboratory, Richland, Washington. Available online at http://sbms.pnl.gov/standard/1e/1e00t010.htm

PNNL. 2006a. Document Control. Standards-Based Management System, Pacific Northwest National Laboratory, Richland, Washington. Available online at http://sbms.pnl.gov/standard/2m/2m00t010.htm

PNNL. 2006b. Policies and Standards. Standards-Based Management System, Pacific Northwest National Laboratory, Richland, Washington. Available online at http://sbms.pnl.gov/private/policies/bp00t010.htm 
PNNL 2007a. Hazardous Materials, Packaging and Shipping. Standards-Based Management System, Pacific Northwest National Laboratory, Richland, Washington. Available online at http://sbms.pnl.gov/standard/66/6600t010.htm

PNNL. 2007b. Planning, Assessment, and Analysis. Standards-Based Management System, Pacific Northwest National Laboratory, Richland, Washington. Available online at http://sbms.pnl.gov/standard/18/1800t010.htm

PNNL. 2007c. Price-Anderson Amendments Act. Standards-Based Management System, Pacific Northwest National Laboratory, Richland, Washington. Available online at http://sbms.pnl.gov/standard/11/1100t010.htm

PNNL. 2007d. Publishing Scientific and Technical Information. Standards-Based Management System, Pacific Northwest National Laboratory, Richland, Washington. Available online at http://sbms.pnl.gov/standard/80/8000t010.htm

PNNL. 2007e. Purchasing Goods and Services. Standards-Based Management System, Pacific Northwest National Laboratory, Richland, Washington. Available online at http://sbms.pnl.gov/standard/3i/3i00t010.htm

PNNL. 2007f. Safety Software. Standards-Based Management System, Pacific Northwest National Laboratory, Richland, Washington. Available online at http://sbms.pnl.gov/standard/6e/6e00t010.htm

PNNL. 2007g. Sample Handling, Archival, and Disposal. Standards-Based Management System, Pacific Northwest National Laboratory, Richland, Washington. Available online at http://sbms.pnl.gov/standard/2h/2h00t010.htm

PNNL. 2007h. Software. Standards-Based Management System, Pacific Northwest National Laboratory, Richland, Washington. Available online at http://sbms.pnl.gov/standard/94/9400t010.htm

PNNL. 2007i. Waste, Managing. Standards-Based Management System, Pacific Northwest National Laboratory, Richland, Washington. Available online at http://sbms.pnl.gov/standard/0f/0f00t010.htm

ESL QAP. Environmental Sciences Laboratory QA Plan, current revision. Pacific Northwest National Laboratory, Richland, Washington.

RCRA - Resource Conservation and Recovery Act of 1976. 1976. Public Law 94-580, as amended, 90 Stat. 2795, 42 USC 6901 et seq.

U.S. Geological Survey. 1977. National Handbook of Recommended Methods for Water Data Acquisition. Office of Water Data Coordination. Reston, Virginia.

WAC 173-160. “Minimum Standards for Construction and Maintenance of Wells.” Washington Administrative Code, Olympia, Washington. 
Appendix A

\section{EM-20 Roadmap Project Quality Control Plan}





\section{Appendix A}

\section{EM-20 Roadmap Project Quality Control Plan}

\section{A.1 Introduction}

This appendix describes the basic methods and procedures to implement a quality control task for sampling and analysis conducted in association with the EM-20 Roadmap Project. The QC practices described in this QAPjP help to evaluate whether samples free of contamination are obtained during sampling and that the laboratory performed sample analyses within the accuracy and precision limits required by the project.

NOTE: Individual work plans or test plans may identify different QC targets with appropriate justification. The justification shall be documented and approved by the Project Manager with concurrent from the project Quality Engineer. This record shall be maintained in the project files.

Most of the information in this appendix applies only to groundwater samples. Quality control practices and requirements that pertain to soil and sediment samples are described in section A.5.

The primary objectives of this QAPjP are listed below:

1. Identify the QC elements selected for the EM-20 Roadmap Project

2. Provide DQO for reporting limits, precision, accuracy, and completeness

3. Indicate actions that are to be taken for out of tolerance data.

\section{A.2 Technical Requirements}

The technical requirements for QC are divided into two types - components that provide checks on field and laboratory activities (Field QC) and factors that help to monitor laboratory performance (Laboratory QC). Each type of QC sample has required frequencies and acceptance criteria.

The following guidance documents were used as aids in determining the QC elements necessary for the Groundwater Performance Assessment Project:

1. Quality Assurance Manual for the Waste Management Branch Investigations (EPA 910/9-86-00).

2. Resource Conservation and Recovery Act (RCRA) Groundwater Monitoring Technical Enforcement Guidance Document (EPA/OSWER-9950.1).

3. Test Methods for Evaluating Solid Waste: Physical/Chemical Methods, SW-846, Third Edition (EPA/SW-846).

4. Handbook for Analytical Quality Control in Water and Wastewater Laboratories (EPA-600/4-79-019).

5. Hanford Analytical Services Quality Assurance Requirements Documents (HASQARD) (DOE/RL-96-68). 
QC elements were selected based on the needs of the project and value that results from each type of sample will add to the database.

\section{A.2.1 Field Quality Control}

To indicate whether samples are collected in a consistent manner and are properly preserved, three types of QC samples will be collected before or during sampling:

1. Sampling Event Blanks - These samples will be prepared by the sampling team before traveling to a sampling site. A preserved bottle set, identical to the set that will be used for sample collection in the field, will be filled with reagent water (carbon free, de-ionized water). Dead water from well 699-S11-E12AP is used for low-level tritium. The bottles will be sealed by the sampling team and transported unopened to the field in the same storage container that will be used for the samples collected that day. These samples will be typically analyzed for the same constituents as the samples from the associated well.

2. Equipment Blanks - Reagent water will be passed through the pump or manifold after decontamination (sometimes just prior to sampling) to collect blank samples identical to a set that will be collected in the field. Preserved bottles will be used. The equipment blank bottles will be placed in the same container as the associated field samples and not removed from the container until delivery to the laboratory.

3. Field Duplicates - A replicate sample that is collected at one well. After each type of bottle is filled, a second, identical bottle will be filled for each type of analysis as directed by chain-of-custody requirements. Both sets of samples will be stored and transported together.

Using several types of field blank samples provides checks on bottle cleanliness, preservative purity, equipment decontamination, proper storage and transport of samples, and reveals whether or not samples may have been contaminated during collection. Sampling in replicate provides information about sampling reproducibility. Field QC sample frequencies are shown in Table A.1. In addition to the evaluation characteristics described in Table A.1, the field QC samples also provide a check on the analytical results. The field QC data are designed to give an overall impression of the performance of the sampling and analysis of the IFC Project; however, individual data points associated with field QC samples that are outside of the acceptance criteria are flagged in the database. 
Table A.1. Quality Control Samples

\begin{tabular}{|c|c|c|}
\hline Sample Type & $\begin{array}{c}\text { Field QC } \\
\text { Primary Characteristics Evaluated }\end{array}$ & Frequency \\
\hline Sample event blank & Contamination from containers or transportation & 1 per 20 wells sampled \\
\hline Equipment blank & Contamination from non-dedicated equipment & As needed ${ }^{(a)}$ \\
\hline Replicate/duplicate samples & Reproducibility & 1 per 20 wells sampled \\
\hline Sample Type & $\begin{array}{c}\text { Laboratory QC } \\
\text { Primary Characteristics Evaluated }\end{array}$ & Frequency \\
\hline Method blanks & Laboratory contamination & 1 per batch \\
\hline Lab duplicates & Laboratory reproducibility & (b) \\
\hline Matrix spikes & Matrix effect and laboratory accuracy & (b) \\
\hline Matrix spike duplicates & Laboratory reproducibility/accuracy & (b) \\
\hline Surrogates & Recovery/yield & (b) \\
\hline Laboratory control samples & Method accuracy & 1 per batch \\
\hline \multicolumn{3}{|c|}{$\begin{array}{l}\text { (a) For portable Grundfos pumps, equipment blanks are collected } 1 \text { per } 10 \text { well trips. Whenever a new type of non- } \\
\text { dedicated equipment is used, an equipment blank shall be collected every time sampling occurs until it can be } \\
\text { shown that less-frequent collection of equipment blanks is adequate to monitor the decontamination procedure } \\
\text { for the nondedicated equipment. } \\
\text { (b) As defined in the laboratory contract or QA plan and/or analysis procedures. } \\
\text { QA = Quality assurance. } \\
\text { QC = Quality control. }\end{array}$} \\
\hline
\end{tabular}

The results of each type of field QC sample are evaluated according to criteria defined in Table A.2.

Table A.2. Field and Laboratory QC Elements and Acceptance Criteria

\begin{tabular}{|c|c|c|c|}
\hline Method & QC Element & Acceptance Criteria & Corrective Action \\
\hline \multicolumn{4}{|c|}{ General Chemical Parameters } \\
\hline \multirow{7}{*}{$\begin{array}{l}\text { Alkalinity - EPA } 600 \text { Series, } 310.1 \\
\text { Chemical Oxygen Demand - EPA } 600 \\
\text { Series, } 410.4 \\
\text { Conductivity - EPA } 600 \text { Series, } 120.1 \\
\text { Oil and Grease - EPA } 600 \text { Series, } \\
413.1 \\
\text { pH - EPA } 600 \text { Series, } 150.1 \\
\text { Total Dissolved Solids - EPA } 600 \\
\text { Series, } 160.1 \\
\text { Total Organic Carbon - SW-846, } 9060 \\
\text { Total Organic Halides - SW-846, } 9020\end{array}$} & $\mathrm{MB}^{(\mathrm{a})}$ & $<\mathrm{MDL}$ & Flagged with "C" \\
\hline & LCS & $80-120 \%$ recovery $^{(b)}$ & Data reviewed $^{(\mathrm{c})}$ \\
\hline & DUP & $\pm 20 \% \mathrm{RPD}^{(\mathrm{b})}$ & Data reviewed $^{(\mathrm{c})}$ \\
\hline & $\mathrm{MS}^{(\mathrm{d})}$ & $75-125 \%$ recovery $^{(\mathrm{b})}$ & Flagged with "N" \\
\hline & EB, FTB & $<2 X$ MDL & Flagged with "Q" \\
\hline & Field Duplicate & $\pm 20 \% \mathrm{RPD}^{(\mathrm{e})}$ & Flagged with "Q" \\
\hline & & & \\
\hline \multicolumn{4}{|c|}{ Ammonia and Anions } \\
\hline \multirow{6}{*}{$\begin{array}{l}\text { Ammonia - EPA } 600 \text { Series, } 350.1 \\
\text { Anions by IC - EPA } 600 \text { Series, } 300.0 \\
\text { Cyanide - SW-846, } 9012\end{array}$} & MB & $<$ MDL & Flagged with "C" \\
\hline & LCS & $80-120 \%$ recovery ${ }^{(\mathrm{b})}$ & Data reviewed $^{(\mathrm{c})}$ \\
\hline & DUP & $\pm 20 \% \mathrm{RPD}^{(\mathrm{b})}$ & Data reviewed $^{(\mathrm{c})}$ \\
\hline & MS & $75-125 \%$ recovery $^{(b)}$ & Flagged with “N” \\
\hline & EB, FTB & $<2 X$ MDL & Flagged with "Q" \\
\hline & Field Duplicate & $\pm 20 \% \mathrm{RPD}^{(\mathrm{e})}$ & Flagged with "Q" \\
\hline \multicolumn{4}{|c|}{ Metals } \\
\hline \multirow{2}{*}{$\begin{array}{l}\text { Arsenic - SW-846, } 7060 \\
\text { Cadmium - SW-846, } 7131\end{array}$} & MB & $<$ CRDL & Flagged with "C" \\
\hline & LCS & $80-120 \%$ recovery ${ }^{(\mathrm{b})}$ & Data reviewed $^{(\mathrm{C})}$ \\
\hline
\end{tabular}


Table A.2. (contd)

\begin{tabular}{|c|c|c|c|c|c|}
\hline \multicolumn{3}{|c|}{$\begin{array}{l}\text { Method } \\
\end{array}$} & QC Element & Acceptance Criteria & Corrective Action \\
\hline \multirow{4}{*}{\multicolumn{3}{|c|}{$\begin{array}{l}\text { Chromium - SW-846, } 7191 \\
\text { Lead - SW-846, 7421 } \\
\text { Mercury - SW-846, } 7470 \\
\text { Selenium - SW-846, } 7740 \\
\text { Thallium - SW-846, } 7841 \\
\text { ICP Metals - SW-846, 6010 } \\
\text { ICP/MS Metals - SW-846, } 6020\end{array}$}} & $\begin{array}{l}\text { MS } \\
\text { MSD }\end{array}$ & $\begin{array}{l}75-125 \% \text { recovery }^{(\mathrm{b})} \\
\pm 20 \% \mathrm{RPD}^{(\mathrm{b})}\end{array}$ & $\begin{array}{l}\text { Flagged with “N” } \\
\text { Data reviewed }^{(\mathrm{c})}\end{array}$ \\
\hline & & & EB, FTB & $<2 X$ MDL & Flagged with "Q" \\
\hline & & & Field Duplicate & $\pm 20 \% \mathrm{RPD}^{(\mathrm{e})}$ & Flagged with "Q" \\
\hline & & & & & \\
\hline \multicolumn{6}{|c|}{ Radiological Parameters } \\
\hline \multirow{7}{*}{\multicolumn{3}{|c|}{$\begin{array}{l}\text { Gamma Scan } \\
\text { Gross Alpha - SW-846, } 9310 \\
\text { Gross Beta - SW-846, } 9310 \\
\text { Iodine-129 } \\
\text { Plutonium (isotopic) } \\
\text { Strontium-89/90 } \\
\text { Technetium-99 } \\
\text { Tritium - SW-846, 906.0 } \\
\text { Tritium (low-level) } \\
\text { Uranium (isotopic) } \\
\text { Uranium (total) }\end{array}$}} & MB & $<2 \mathrm{X}$ MDA & Flagged with "B" \\
\hline & & & LCS & $70-130 \%$ recovery & Data reviewed $^{(\mathrm{c})}$ \\
\hline & & & DUP & $\pm 20 \% \mathrm{RPD}$ & Data reviewed $^{(\mathrm{c})}$ \\
\hline & & & $\mathrm{MS}^{(\mathrm{h})}$ & $60-140 \%$ recovery & Flagged with "N" \\
\hline & & & EB, FTB & $<2 \mathrm{X}$ MDA & Flagged with "Q" \\
\hline & & & Field Duplicate & $\pm 20 \% \operatorname{RPD}(5)$ & Flagged with "Q" \\
\hline & & & & & \\
\hline \multicolumn{6}{|c|}{ (a) Does not apply to $\mathrm{pH}$. } \\
\hline \multirow{8}{*}{\multicolumn{6}{|c|}{$\begin{array}{l}\text { (b) Laboratory-determined, statistically derived control limits may also be used. Such limits are reported } \\
\text { the data. } \\
\text { (c) After review, corrective actions are determined on a case-by-case basis. Corrective actions may inclu } \\
\text { laboratory recheck or flagging the data as suspect (Y flag) or rejected (R flag). } \\
\text { (d) Applies to total organic carbon and total organic halides only. } \\
\text { (e) Applies only in cases where one or both results are greater than } 5 X \text { the detection limit. } \\
\text { (f) Determined by the laboratory based on historical data. Control limits are reported with the data. } \\
\text { (g) For common laboratory contaminants such as acetone, methylene chloride, 2-butanone, toluene, and } \\
\text { phthalate esters, the acceptance criteria is < } 5 \text { X MDL. } \\
\text { (h) Applies only to technetium-99 and total uranium analyses. }\end{array}$}} \\
\hline & & & & & \\
\hline & & & & & \\
\hline & & & & & \\
\hline & & & & & \\
\hline & & & & & \\
\hline & & & & & \\
\hline & & & & & \\
\hline $\mathrm{B}, \mathrm{C}$ & $=$ & \multirow{4}{*}{\multicolumn{4}{|c|}{$\begin{array}{l}\text { Possible laboratory contamination (analyte was detected in the associated method blank). } \\
\text { result may be biased (associated matrix spike result was outside the acceptance limits). } \\
\text { problem with associated field QC sample (blank and/or duplicate results were out of limits). } \\
\text { Laboratory matrix duplicate. }\end{array}$}} \\
\hline & & & & & \\
\hline & & & & & \\
\hline DUP & $=$ & & & & \\
\hline & & \multicolumn{3}{|c|}{$\begin{array}{l}\text { Laboratory matrix duplicate. } \\
\text { Equipment blank. }\end{array}$} & \\
\hline FTB & & \multicolumn{4}{|l|}{ Full trip blank. } \\
\hline FXR & & \multicolumn{4}{|l|}{$\begin{array}{l}\text { Full trip blank. } \\
\text { Field transfer blank. }\end{array}$} \\
\hline & & \multicolumn{4}{|l|}{ Gas chromatography. } \\
\hline ICP & $=$ & \multicolumn{4}{|c|}{ Inductively coupled plasma. } \\
\hline $\mathrm{ICP} / \mathrm{M}$ & $=$ & \multicolumn{4}{|c|}{ Inductively coupled plasma-mass spectrometry. } \\
\hline LCS & $=$ & \multicolumn{4}{|c|}{ Laboratory control sample. } \\
\hline & $=$ & \multicolumn{4}{|c|}{ Method blank. } \\
\hline MDA & $=$ & \multicolumn{4}{|c|}{ Minimum detectable activity. } \\
\hline MDL & & \multicolumn{4}{|c|}{ Method detection limit. } \\
\hline & $=$ & \multicolumn{4}{|c|}{ Matrix spike. } \\
\hline MSD & $=$ & \multicolumn{4}{|c|}{ Matrix spike duplicate. } \\
\hline PCBs & $=$ & \multicolumn{4}{|c|}{ Polychlorinated biphenyls. } \\
\hline RPD & & \multirow{2}{*}{\multicolumn{4}{|c|}{$\begin{array}{l}\text { Relative percent difference. } \\
\text { Surrogate }\end{array}$}} \\
\hline SUR & $=$ & & & & \\
\hline
\end{tabular}


Bias will be assessed by comparing a measured value to a known or accepted reference value or the recovery of a known amount of spiked contaminant into a sample (i.e., a matrix spike). For a matrix spike (MS) bias caused by matrix effects will be calculated as follows in Equation (A.1):

$$
\mathrm{B}=(\mathrm{Xs}-\mathrm{Xu})-\mathrm{K}
$$

Where

$\mathrm{X}=$ measured value of spiked sample

$\mathrm{Xu}=$ sample or miscellaneous contribution

$\mathrm{K}=$ known value of spike

Using the following Equation (A.2) yields percent recovery (\%R):

$$
\% \mathrm{R}=100(\mathrm{Xs}-\mathrm{Xu}) / \mathrm{K}
$$

Analytical precision will be determined by analyzing duplicates (field or lab). Precision is expressed as either percent relative standard deviation (RSD) or relative percent difference (RPD). Duplicate results will be flagged if the results of both samples are quantifiable (i.e., the result is greater than the 5 times the instrument detection limit [IDL]/method detection limit [MDL]/minimum detectable activity [MDA]) and the RPD is greater than 20\%. The RPD is calculated using Equation (A.3):

$$
\mathrm{RPD}=\frac{\mathrm{D}_{1}-\mathrm{D}_{2}}{\left(\mathrm{D}_{1}+\mathrm{D}_{2}\right) / 2} \times 100
$$

Where

$\mathrm{D} 1=$ original sample value

$\mathrm{D} 2$ = duplicate sample value

When more than two data values are present, precision is calculated as the RSD (Equation [A.4]):

$$
\mathrm{RSD}=\frac{\text { standard deviation }}{\text { mean }} \times 100
$$

\section{A.2.2 Quality Control in the Laboratory}

The ability to perform sample analyses within the limits established by the project will be monitored in several ways. This QAPjP governs laboratory work performed by staff participating in the EM-20 Roadmap Project. The work activities in the laboratories will be periodically reviewed, including selected laboratories of subcontracted EM-20 Roadmap Project collaborators. The laboratory quality assurance effort includes a comprehensive quality control program, which includes the use of matrix spikes, matrix duplicates, matrix spike duplicates, laboratory control samples, surrogates, tracers, and blanks. These samples are recommended in the guidance documents and are required by U.S. Environmental Protection Agency (EPA) protocol.

Matrix Duplicate - An intra-laboratory split sample used to evaluate the precision of a method in a given sample matrix. 
Matrix Spike - An aliquot of a sample spiked with a known concentration of target analyte(s). The MS will be used to assess the bias of a method in a given sample matrix. Spiking will be done prior to sample preparation and analysis.

Matrix Spike Duplicate - A replicate spiked aliquot of a sample subjected to the entire sample preparation and analytical process. The results from these samples will be used to determine the bias and precision of a method in a given sample matrix.

Laboratory Control Sample - A control matrix spike (e.g., deionized water) spiked with analytes representative of the target analytes or a certified reference material used to evaluate laboratory accuracy.

Method Blank - An analyte-free matrix to which all reagents are added in the same volumes or proportions as used in sample processing. The method blank will be carried through the complete sample preparations and analytical procedure and used to quantify contamination resulting from the analytical process.

Tracers - A tracer is a known quantity of a chemical or radioactive isotope that is different from that of the isotope of interest but is expected to behave similarly and is added to an aliquot of sample. Sample results are generally corrected based on tracer recovery.

The samples are analyzed within the holding times specified by the analysis procedure. In some instances, constituents in samples not analyzed within the holding time may be compromised by volatilization, decomposition or other chemical changes. Data from samples analyzed outside the holding time are flagged in the EM-20 Roadmap Project database with an H. The holding times for constituents analyzed by the EM-20 Roadmap Project are listed in Table A.3.

Table A.3. EM-20 Roadmap Project Holding Times

\begin{tabular}{||l|l|l||}
\hline \multicolumn{1}{|c|}{ Constituents } & \multicolumn{1}{|c|}{ Methods $^{(\mathbf{a})}$} & \multicolumn{1}{c|}{ Holding Times } \\
\hline \hline ICP metals & SW-846, 6010 & 6 months \\
\hline ICP-MS & SW-846, 6020 & 6 months \\
\hline Arsenic & SW-846, 7060 & 6 months \\
\hline Lead & SW-846, 7421 & 6 months \\
\hline Mercury & SW-846, 7470/7471 & 28 days \\
\hline Selenium & SW-846, 7740 & 6 months \\
\hline Thallium & SW-846, 7841 & 6 months \\
\hline Alkalinity & EPA 600 Series, 310.1 & 14 days \\
\hline Cyanide & SW-846, 9010/9012 & 14 days \\
\hline Bromide & EPA 600 Series, 300.0 & 28 days \\
\hline Chloride & EPA 600 Series, 300.0 & 28 days \\
\hline Fluoride & EPA 600 Series, 300.0 & 28 days \\
\hline Nitrate & EPA 600 Series, 300.0 & 48 hours \\
\hline Nitrite & EPA 600 Series, 300.0 & 48 hours \\
\hline Phosphate & EPA 600 Series, 300.0 & 48 hours \\
\hline Sulfate & EPA 600 Series, 300.0 & 28 days \\
\hline Total organic carbon & SW-846, 9060 & 28 days \\
\hline Total organic halides & SW-846, 9020 & 28 days \\
\hline Chemical oxygen demand & EPA 600 Series, 410.4 & 28 days \\
\hline (a) EPA/SW-846, as amended. & \multicolumn{2}{|l}{} \\
\hline
\end{tabular}


Other tools are used by the project to evaluate analytical work. Double-blind standards of the constituents of concern will be used to evaluate laboratory performance. Because the results of doubleblind standards provide information on laboratory precision and accuracy, these standards are useful tools to verify that the project DQOs is being met. Table A.4 lists the typical blind-standard constituents. The list of constituents is subject to change based on need. Specific information about the constituents used and their spiking levels will be maintained in the project files.

Table A.4. Blind-Standard Constituents and Schedule

\begin{tabular}{||l|l|l||}
\hline \multicolumn{1}{|c|}{ Constituents } & \multicolumn{1}{c||}{$\begin{array}{c}\text { Recommended } \\
\text { Recovery (\%)(a) }\end{array}$} & \multicolumn{1}{c||}{ Precision (\%RSD)(a) } \\
\hline \hline Fluoride & $\pm 25 \%$ & $\pm 25 \%$ \\
\hline Nitrate & $\pm 25 \%$ & $\pm 25 \%$ \\
\hline Cyanide & $\pm 25 \%$ & $\pm 25 \%$ \\
\hline Chromium & $\pm 20 \%$ & $\pm 20 \%$ \\
\hline Total Organic & Varies according to & Varies according to \\
Carbon(b) & spiking compound & Varies according to \\
\hline Total Organic & Varies according to & spiking compound \\
Halides(c) & spiking compound & $\pm 20 \%$ \\
\hline Gross alpha(d) & $70-130 \%$ & $\pm 20 \%$ \\
\hline Gross beta(e) & $70-130 \%$ & $\pm 20 \%$ \\
\hline Tritium & $70-130 \%$ & $\pm 20 \%$ \\
\hline Tritium (low level) & $70-130 \%$ & $\pm 20 \%$ \\
\hline Cobalt-60 & $70-130 \%$ & $\pm 20 \%$ \\
\hline Strontium-90 & $70-130 \%$ & $\pm 20 \%$ \\
\hline Technetium-99 & $70-130 \%$ & $\pm 20 \%$ \\
\hline Iodine-129 & $70-130 \%$ & $\pm 20 \%$ \\
\hline Cesium-137 & $70-130 \%$ & $\pm 20 \%$ \\
\hline Uranium & $70-130 \%$ & $\pm 20 \%$ \\
\hline Plutonium-239/240 & $70-130 \%$ & \\
\hline & & \\
\hline
\end{tabular}

Blind standards are prepared by spiking matrix groundwater and deionized water with known concentrations of constituents of interest. Spiking concentrations range from MDA or MDL, depending on the constituent measured, to the upper limit of concentration determined in groundwater on the Hanford Site. The matrix groundwater wells chosen are 699-49-100C for radiochemical analytes, and total organic halides (TOX); and 699-19-88 for cyanide, anions, inductively coupled plasma (ICP) metals, and total organic carbon (TOC). Deionized water is used to prepare VOCs. Well 699-49-100C is located to the west of the Hanford Site. Well 699-19-88 is a southern boundary well. Both wells are considered free of the contaminant migration zone. Dead water from well 699-S11-E12AP is used to prepare lowlevel tritium blind standards.

Blind-standard results are evaluated by comparing the laboratory results to the actual spike values. Laboratory precision also is considered as the samples are sent to the laboratory in replicate. Laboratory results are evaluated based on the recovery and precision criteria listed in Table A.4. Results outside of these control limits are investigated and appropriate actions are taken, if necessary. 


\section{A.3 Data Quality Objectives}

DQOs are defined for reporting limits, precision, accuracy, and completeness. Groundwater monitoring plans or sampling analysis plans specify whether or not a particular site has more stringent DQOs than those specified in this QAPjP.

Limits for precision and accuracy for chemical analyses are based on criteria stipulated in the methods (e.g., EPA/SW-846, EPA 600 series). Precision and accuracy limits for radiochemical results are specified in the laboratory contract.

Completeness is defined as the percentage of data points judged to be valid. The percent complete each quarter should be at least $85 \%$.

Reporting limits for radiochemical constituents are defined in individual test plans. Reporting limits will be based on the research needs, but regulatory reporting limits and actual reporting limits are listed in Table A.5 for radiochemical constituents as a reference point. For chemical constituents, MDLs as low as one third the EPA drinking water standards are preferred. In some cases, MDLs that are one third the regulatory limit are not feasible (e.g., pentachlorophenol and cadmium). Because MDLs change frequently, these values are not provided in this document.

Table A.5. Reporting Limits for Radiochemical Constituents

\begin{tabular}{|c|c|c|c|c|c|}
\hline $\begin{array}{l}\text { Constituent of } \\
\text { Concern }\end{array}$ & Method & CAS \# & DWS & 1/3 DWS & RDL \\
\hline Gross Alpha & Gross Alpha-GA & $12587-46-1$ & $15 \mathrm{pCi} / \mathrm{L}^{*}$ & $5 \mathrm{pCi} / \mathrm{L}^{*}$ & $3 \mathrm{pCi} / \mathrm{L}$ \\
\hline Gross Beta & Gross Beta - GB & $12587-47-2$ & N/A & N/A & $4 \mathrm{pCi} / \mathrm{L}$ \\
\hline Cobalt-60 & Gamma Spec & 10198-40-0 & $100 \mathrm{pCi} / \mathrm{L}$ & $33 \mathrm{pCi} / \mathrm{L}$ & $25 \mathrm{pCi} / \mathrm{L}$ \\
\hline Cesium-137 & & $10045-97-3$ & $200 \mathrm{pCi} / \mathrm{L}$ & $67 \mathrm{pCi} / \mathrm{L}$ & $15 \mathrm{pCi} / \mathrm{L}$ \\
\hline Europium-152 & & & & & $50 \mathrm{pCi} / \mathrm{L}$ \\
\hline Europium-154 & & & $200 \mathrm{pCi} / \mathrm{L}$ & $67 \mathrm{pCi} / \mathrm{L}$ & $50 \mathrm{pCi} / \mathrm{L}$ \\
\hline Europium-155 & & & $600 \mathrm{pCi} / \mathrm{L}$ & $200 \mathrm{pCi} / \mathrm{L}$ & $50 \mathrm{pCi} / \mathrm{L}$ \\
\hline Tritium & $\mathrm{H}-3$ & $10028-17-8$ & $20,000 \mathrm{pCi} / \mathrm{L}$ & $6700 \mathrm{pCi} / \mathrm{L}$ & $400 \mathrm{pCi} / \mathrm{L}$ \\
\hline Tritium & H-3 (LL) & N/A & N/A & N/A & $10 \mathrm{pCi} / \mathrm{L}$ \\
\hline Iodine-129 & I-129 & $10043-66-0$ & $1 \mathrm{pCi} / \mathrm{L}$ & $0.33 \mathrm{pCi} / \mathrm{L}$ & $5 \mathrm{pCi} / \mathrm{L}$ \\
\hline Iodine-129 & I-129 (LL) & N/A & $\mathrm{N} / \mathrm{A}$ & N/A & $1 \mathrm{pCi} / \mathrm{L}$ \\
\hline 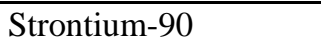 & Sr-89/Sr-90 & $10098-97-2$ & $8 \mathrm{pCi} / \mathrm{L}$ & $2.7 \mathrm{pCi} / \mathrm{L}$ & $2 \mathrm{pCi} / \mathrm{L}$ \\
\hline Technetium-99 & Tc-99 & 14133-76-7 & $900 \mathrm{pCi} / \mathrm{L}$ & $300 \mathrm{pCi} / \mathrm{L}$ & $15 \mathrm{pCi} / \mathrm{L}$ \\
\hline Plutonium-238 & Isotopic Plutonium & & $1.6 \mathrm{pCi} / \mathrm{L}$ & $0.5 \mathrm{pCi} / \mathrm{L}$ & $1 \mathrm{pCi} / \mathrm{L}$ \\
\hline Plutonium-239/240 & Pu-AEA & & $1.2 \mathrm{pCi} / \mathrm{l}$ & $0.4 \mathrm{pCi} / \mathrm{L}$ & $1 \mathrm{pCi} / \mathrm{L}$ \\
\hline Uranium-233 & Isotopic Uranium & $13968-55-3$ & $20 \mathrm{pCi} / \mathrm{L}$ & $6.7 \mathrm{pCi} / \mathrm{L}$ & $1 \mathrm{pCi} / \mathrm{L}$ \\
\hline Uranium-234 & Isotopic Uranium & $13966-29-5$ & $20 \mathrm{pCi} / \mathrm{L}$ & $6.7 \mathrm{pCi} / \mathrm{L}$ & $1 \mathrm{pCi} / \mathrm{L}$ \\
\hline Uranium-235 & Uranium-AEA & 15117-96-1 & $24 \mathrm{pCi} / \mathrm{L}$ & $8 \mathrm{pCi} / \mathrm{L}$ & $1 \mathrm{pCi} / \mathrm{L}$ \\
\hline Uranium-238 & & U-238 & $24 \mathrm{pCi} / \mathrm{L}$ & $8 \mathrm{pCi} / \mathrm{L}$ & $1 \mathrm{pCi} / \mathrm{L}$ \\
\hline $\begin{array}{l}\text { Total alpha energy } \\
\text { emitted from Radium }\end{array}$ & Total Radium & N/A & N/A & N/A & $1 \mathrm{pCi} / \mathrm{L}$ \\
\hline Uranium (elemental) & Total Uranium & N/A & $30 \mu \mathrm{g} / \mathrm{L}$ & $10 \mu \mathrm{g} / \mathrm{L}$ & $0.1 \mu \mathrm{g} / \mathrm{L}$ \\
\hline \multicolumn{6}{|c|}{ * Excluding uranium } \\
\hline \multicolumn{6}{|c|}{ CAS\# = Chemical abstract service number. } \\
\hline \multicolumn{6}{|c|}{ DWS $=$ Drinking water standard. } \\
\hline \multicolumn{6}{|c|}{ N/A $=$ Not applicable. } \\
\hline \multicolumn{6}{|c|}{ RDL $=$ Required detection limit. } \\
\hline
\end{tabular}




\section{A.4 Reporting and Deliverables Requirements}

The results of the blind standards and the field QC samples will be provided through current analytical reporting procedures. The QC analytical results will be reviewed and compiled in the IFC database.

All project records associated with quality control are maintained in accordance with the RIDS for the EM-20 Roadmap Project.

\section{A.5 Requirements for Soil and Sediment Samples}

The EM-20 Roadmap Project will analyze sediment samples in support of site-characterization activities. The nature of this work precludes specification of many of the requirements listed previously for groundwater samples. Therefore, the types, quantities, and acceptance criteria for field and/or laboratory QC samples are specified in the characterization plan and specific test plans for individual experiments. Table A.6 lists the maximum recommended holding times for common analytes in soils. Radionuclides are not included in the table.

Table A.6. Holding Times for Sediment Analyses

\begin{tabular}{|l|l|l||}
\hline \multicolumn{1}{|c|}{ Constituents } & \multicolumn{1}{|c|}{ Methods } & \multicolumn{1}{c|}{ Holding Times } \\
\hline \hline ICP metals & SW-846, 6010 & 6 months \\
\hline ICP-MS & SW-846, 6020 & 6 months \\
\hline Arsenic & SW-846, 7060 & 6 months \\
\hline Lead & SW-846, 7421 & 6 months \\
\hline Mercury & SW-846, 7470/7471 & 28 days \\
\hline Selenium & SW-846, 7740 & 6 months \\
\hline Thallium & SW-846, 7841 & 6 months \\
\hline Alkalinity & EPA 600 Series, 310.1 & 14 days \\
\hline Cyanide & SW-846, 9010/9012 & 14 days \\
\hline Bromide & EPA 600 Series, 300.0 & 28 days \\
\hline Chloride & EPA 600 Series, 300.0 & 28 days \\
\hline Fluoride & EPA 600 Series, 300.0 & 28 days \\
\hline Nitrate & EPA 600 Series, 300.0 & 48 hours \\
\hline Nitrite & EPA 600 Series, 300.0 & 48 hours \\
\hline Phosphate & EPA 600 Series, 300.0 & 48 hours \\
\hline Sulfate & EPA 600 Series, 300.0 & 28 days \\
\hline Total organic carbon & SW-846, 9060 & 28 days \\
\hline Total organic halides & SW-846, 9020 & 28 days \\
\hline Chemical oxygen demand & EPA 600 Series, 410.4 & 28 days \\
\hline (a) EPA/SW-846, as amended. & & \\
\hline
\end{tabular}

\section{A.6 References}

DOE/RL-96-68. 1998. Hanford Analytical Services Quality Assurance Requirements Documents. (HASQARD), Volumes 1 through 4, U.S. Department of Energy, Richland, Washington.

DOH. 1990. Washington State Environmental Radiation Program Annual Report. Washington State Department of Health, Olympia, Washington. 
EPA-600/4-79-019. 1979. Handbook for Analytical Quality Control in Water and Wastewater Laboratories. U.S. Environmental Protection Agency, Cincinnati, Ohio.

EPA 910/9-86-00. 1986. Quality Assurance Manual for Waste Management Branch Investigations. U.S. Environmental Protection Agency, Region 10, Seattle, Washington.

EPA/OWSER-9950.1. 1986. Resource Conservation and Recovery Act (RCRA) Groundwater Monitoring Technical Enforcement Guidance Document. U.S. Environmental Protection Agency, Washington, D.C.

EPA/SW-846. 1986, as amended. Test Methods for Evaluating Solid Waste: Physical/Chemical Methods, SW-846, Third Edition. Office of Solid Waste and Emergency Response, U.S. Environmental Protection Agency, Washington, D.C. Available online at http://www.epa.gov/epaoswer/hazwaste/test/sw846.htm

PNNL-145670. 2006. Hanford Site Groundwater Monitoring for Fiscal Year 2005. MJ Hartman, LF Morasch, and WD Webber (eds.), Pacific Northwest National Laboratory, Richland, Washington. 


\section{Appendix B}

Experimental and Modeling Procedures for the EM-20 Roadmap Project 



\section{Appendix B}

\section{Experimental and Modeling Procedures for the EM-20 Roadmap Project}

Table B.1. EM-20 Roadmap Project Procedures and Protocols

\begin{tabular}{|c|c|c|c|}
\hline Method & Analysis & Document Number & Procedure Title \\
\hline $\begin{array}{l}\text { Conduct of Routine } \\
\text { Laboratory Operations }\end{array}$ & General & RPL-OP-001 & $\begin{array}{l}\text { Routine Research Operations } \\
\text { Section } 31 \text { tab } 3 \text { of } \\
\text { RPL Laboratory Handbook }\end{array}$ \\
\hline $\begin{array}{l}\text { Inductively Coupled } \\
\text { Plasma-Optical Emission } \\
\text { Spectroscopy } \\
(\text { ICP-OES)* }\end{array}$ & $\begin{array}{l}\mathrm{Ca}, \mathrm{K}, \mathrm{Mg}, \mathrm{P}, \mathrm{Sr}, \mathrm{Na}, \mathrm{Si} \text {, } \\
\mathrm{Cu}, \mathrm{Fe}, \mathrm{Mn}, \mathrm{S} \text {, and Ti in } \\
\text { water in ppb or moles/L }\end{array}$ & PNNL-AGG-ICP-AES* & $\begin{array}{l}\text { Inductively Couple Plasma - } \\
\text { Optical Emission } \\
\text { Spectrometry (ICP-OES) } \\
\text { Analysis }\end{array}$ \\
\hline $\begin{array}{l}\text { Inductively Coupled } \\
\text { Plasma-Mass } \\
\text { Spectroscopy (ICP-MS) }\end{array}$ & Re, Tc & PNNL-AGG-415 & $\begin{array}{l}\text { Inductively Coupled Plasma } \\
\text { Mass Spectrometric (ICP- } \\
\text { MS) Analysis }\end{array}$ \\
\hline Ion Chromatography & $\begin{array}{l}\mathrm{F}, \mathrm{Cl}, \mathrm{NO} 2, \mathrm{NO} 3, \mathrm{CO} 3 \text {, } \\
\mathrm{SO} 4, \mathrm{PO} 4, \mathrm{PO} 4 \text { in water } \\
\text { in ppm or moles/L }\end{array}$ & *PNNL-AGG-IC-001 & $\begin{array}{l}\text { Determinations by Ion } \\
\text { Chromatography (IC) }\end{array}$ \\
\hline ICP/MS & $\begin{array}{l}\mathrm{Cu}, \mathrm{Fe} \text { in water in ppb } \\
\text { or moles/L }\end{array}$ & $\begin{array}{l}\text { PNL-SAND-3.1 (needs to } \\
\text { be updated) }\end{array}$ & -- \\
\hline KPA & $\begin{array}{l}\mathrm{U} \text { in water in } \mathrm{ppb} \text { or } \\
\text { moles/L }\end{array}$ & Liu et al. 2004 & -- \\
\hline Spectrophotometer & $\begin{array}{l}\mathrm{Fe}(\mathrm{II}) \text { and total Fe in } \\
\mathrm{ppb}\end{array}$ & Kukkadapu et al. 2004 & -- \\
\hline LSC & $\begin{array}{l}\text { Sr90, Tc99, I129, in } \\
\text { dpm/mL }\end{array}$ & $\begin{array}{l}\text { *PNNL-AGG-RRL-002; } \\
\text { Procedures vary slightly } \\
\text { for different } \\
\text { radioisotopes; McKinley } \\
\text { et al. (2006) for Sr90 }\end{array}$ & -- \\
\hline $\begin{array}{l}\text { Solid-State pH Electrode } \\
\text { and Meter }\end{array}$ & pH, Bromide & AGG-PH-001 & pH Measurement \\
\hline X-ray Diffraction (XRD) & Mineralogy & RPL-XRD-PIP & $\begin{array}{l}\text { Operation of Scintag Pad-V } \\
\text { X-Ray Diffractor (RGD \#62) }\end{array}$ \\
\hline $\begin{array}{l}\text { Scanning Electron } \\
\text { Microscopy/ Energy- } \\
\text { Dispersive X-ray } \\
\text { Spectrometry } \\
\text { (SEM/EDS) }\end{array}$ & $\begin{array}{l}\text { Particle morphology, } \\
\text { size, and qualitative } \\
\text { elemental analysis }\end{array}$ & PNL-SP-3 & $\begin{array}{l}\text { Scanning Electron } \\
\text { Microscopy/Energy } \\
\text { Dispersive Spectrometry }\end{array}$ \\
\hline
\end{tabular}




\begin{tabular}{|c|c|c|c|}
\hline Method & Analysis & Document Number & Procedure Title \\
\hline Particle Size Distribution & -- & PNL-MA-567, SA-3 & $\begin{array}{l}\text { Particle-size analysis (Pipette } \\
\text { or hydrometer method); Wet } \\
\text { sieve analysis will be used to } \\
\text { remove sand-size particle }\end{array}$ \\
\hline Hydraulic Conductivity & -- & PNL-MA-567, SA-5 & $\begin{array}{l}\text { Falling head hydraulic } \\
\text { conductivity }\end{array}$ \\
\hline Water Retention & -- & UFA-SK-01 & $\begin{array}{l}\text { Determination of water } \\
\text { retention as a function of } \\
\text { water content using open- } \\
\text { flow centrifugation } \\
\text { techniques }\end{array}$ \\
\hline Water Content & -- & PNL-MA-567, SA-7 & Water Content \\
\hline Bulk Density & -- & PNL-MA-567, SA-8 & Clod density/bulk density \\
\hline Particle Density & -- & PNL-MA-567, SA-9 & $\begin{array}{l}\text { Determining particle density; } \\
\text { necessary for constant head } \\
\text { hydraulic conductivity }\end{array}$ \\
\hline Column Packing & -- & $\begin{array}{l}\text { WHC-IP-0635, GEL-3 } \\
\text { Rev.3 }\end{array}$ & $\begin{array}{l}\text { Moisture relationships of } \\
\text { soils; necessary for constant } \\
\text { head hydraulic conductivity }\end{array}$ \\
\hline $\mathrm{pH} / \mathrm{EC}$ & -- & PNL-G-5-pH/EC & $\begin{array}{l}\text { Measuring } \mathrm{pH} / \mathrm{EC} \text { of low- } \\
\text { level radioactive solutions }\end{array}$ \\
\hline $\begin{array}{l}\text { Saturated column } \\
\text { experiments }\end{array}$ & -- & AGG-SAT-COL-001 & $\begin{array}{l}\text { Conducting saturated column } \\
\text { experiments }\end{array}$ \\
\hline Batch experiments & -- & AGG-BSE-001 & Batch sorption experiments \\
\hline Surface Area & -- & AGG-SA-001 & Measuring Surface area \\
\hline TIC/TOC & $\begin{array}{l}\text { Inorganic C, organic C, } \\
\text { total C }\end{array}$ & *PNNL-AGG-TOC-001 & -- \\
\hline X-ray Fluorescence & $\begin{array}{l}\text { Total analyses of } \\
\text { sediments including Al, } \\
\mathrm{Si}, \mathrm{K}, \mathrm{Ca}, \mathrm{Mg}, \mathrm{Sr}, \mathrm{Ti} \text {, } \\
\text { Fe, Mn, Cu, Ni, Cr, Cs, } \\
\text { U, and others. }\end{array}$ & $\begin{array}{l}\text { *PNNL-AGG-OP- } \\
\text { RGD74-001 }\end{array}$ & -- \\
\hline $\begin{array}{l}\text { Conventional Powder X- } \\
\text { ray Diffraction }\end{array}$ & $\begin{array}{l}\text { Mineral identity (\% } \\
\text { distribution) }\end{array}$ & Qafoku et al. 2005 & -- \\
\hline Digital Autoradiography & $\begin{array}{l}\text { Identify locations of } \\
\text { radioactivity in sediment } \\
\text { thin section and } \\
\text { mixtures of sand and } \\
\text { silt-sized particles. }\end{array}$ & $\begin{array}{l}\text { Zeissler et al 2001; } \\
\text { McKinley et al. } 2001\end{array}$ & -- \\
\hline
\end{tabular}




\begin{tabular}{|c|c|c|c|}
\hline Method & Analysis & Document Number & Procedure Title \\
\hline $\begin{array}{l}\text { Scanning Electron } \\
\text { Microscopy } \\
\text { with WDS }\end{array}$ & $\begin{array}{l}\text { High resolution imaging } \\
\text { of particle morphology } \\
\text { and atomic mass } \\
\text { generally in sediment } \\
\text { thin section; semi } \\
\text { quantitative imaging of } \\
\text { chemical distribution. }\end{array}$ & McKinley et al, 2005 & -- \\
\hline $\begin{array}{l}\text { Transmission Electron } \\
\text { Microscopy with } \\
\text { Selected Area } \\
\text { Diffraction (SAED) }\end{array}$ & $\begin{array}{l}\text { Very high resolution of } \\
\text { single mineral grains in } \\
\text { cross section; local } \\
\text { morphology, structure } \\
\text { and atomic arrangement. }\end{array}$ & $\begin{array}{l}\text { Zachara et al. } 2006 . \\
\text { Selected area diffraction } \\
\text { patterns are interpreted } \\
\text { using the JADE software } \\
\text { (see below) using x-ray } \\
\text { powder diffraction data } \\
\text { (PDF) retrieved from a } \\
\text { standards library (ICDD, } \\
\text { 2003) }\end{array}$ & -- \\
\hline Electron microprobe & $\begin{array}{l}\text { Quantitative, } \\
\text { intermediate sensitivity } \\
\text { chemical mapping in } \\
\text { thin sections. Chemical } \\
\text { transects across } \\
\text { grain/particle } \\
\text { boundaries. }\end{array}$ & $\begin{array}{l}\text { Wang et al. 2005b; } \\
\text { Catalano et al. } 2006\end{array}$ & -- \\
\hline $\begin{array}{l}\text { X-ray fluorescence } \\
\text { microprobe }\end{array}$ & $\begin{array}{l}\text { High sensitivity, semi } \\
\text { quantitative mapping of } \\
\text { element distributions in } \\
\text { sediment thin sections at } \\
\text { scales of } 10 \mu \mathrm{m} \text {. }\end{array}$ & $\begin{array}{l}\text { Liu et al. 2004; } \\
\text { Fredrickson et al. } 2004\end{array}$ & -- \\
\hline $\begin{array}{l}\text { X-ray absorption } \\
\text { spectroscopy }\end{array}$ & $\begin{array}{l}\text { Determination of } \\
\text { element coordination } \\
\text { structure, nearest } \\
\text { neighbors, and bond } \\
\text { distances in } \\
\text { contaminated sediment. }\end{array}$ & $\begin{array}{l}\text { Catalano et al. 2004; } \\
\text { Catalano et al. 2006 } \\
\text { Basic experimental } \\
\text { synchrotron } \\
\text { measurements are } \\
\text { modeled with FEFF, } \\
\text { FEFFIT, and IFEFFIT } \\
\text { (see below) to extract } \\
\text { molecular information. }\end{array}$ & -- \\
\hline Synchrotron diffraction & $\begin{array}{l}\text { Identification of mineral } \\
\text { structures } \\
\text { In sediment thin } \\
\text { sections. }\end{array}$ & $\begin{array}{l}\text { Catalano et al. } 2004 . \\
\text { Mineral structures are } \\
\text { derived by application of } \\
\text { the FIT2D software (see } \\
\text { below). }\end{array}$ & -- \\
\hline
\end{tabular}




\begin{tabular}{|c|c|c|c|}
\hline Method & Analysis & Document Number & Procedure Title \\
\hline $\begin{array}{l}\text { Cryogenic laser induced } \\
\text { fluorescence } \\
\text { spectroscopy (CLIFS) }\end{array}$ & $\begin{array}{l}\text { Vibronic spectra of } \\
\text { U(VI) in water and } \\
\text { solids to establish } \\
\text { molecular and } \\
\text { mineralogic } \\
\text { environment. }\end{array}$ & $\begin{array}{l}\text { Wang et al. } 2004 \text { (for } \\
\text { aqueous solutions); Wang } \\
\text { et al. 2005a (for solids). } \\
\text { Data analysis is } \\
\text { performed using the } \\
\text { IGOR and Globals } \\
\text { programs (see below). }\end{array}$ & -- \\
\hline $\begin{array}{l}\text { Batch kinetic desorption } \\
\text { experiments }\end{array}$ & $\begin{array}{l}\text { Sediments are bathed in } \\
\text { electrolyte of known } \\
\text { composition and the } \\
\text { time-variant release of } \\
\text { contaminants and other } \\
\text { solid associated ions are } \\
\text { monitored by aqueous } \\
\text { phase analyses. }\end{array}$ & $\begin{array}{l}\text { Procedures vary as per } \\
\text { element and its } \\
\text { concentration. Examples } \\
\text { include Liu et al. } 2003 \\
\text { (Cs137); Liu et al. } 2004 \\
\text { (U); McKinley et al. } 2005 \\
\text { (Sr90). Kinetic rate laws } \\
\text { and rate constants are } \\
\text { calculated from the data } \\
\text { using microscopic, } \\
\text { diffusion based transport } \\
\text { models (See below). } \\
\text { Steady state values can } \\
\text { be used to establish } \\
\text { thermodynamic } \\
\text { parameters, such as the } \\
\text { solubility product of a } \\
\text { precipitated contaminant } \\
\text { phase (e.g., Ilton et al. } \\
\text { 2006). }\end{array}$ & -- \\
\hline $\begin{array}{l}\text { Batch adsorption } \\
\text { experiments }\end{array}$ & $\begin{array}{l}\text { Sediments are bathed in } \\
\text { electrolyte of know } \\
\text { composition that has } \\
\text { been spiked with a } \\
\text { contaminant of interest. } \\
\text { The adsorption of the } \\
\text { contaminant is } \\
\text { monitored as a function } \\
\text { of pH, ionic strength, or } \\
\text { ion composition. }\end{array}$ & $\begin{array}{l}\text { Example procedures are } \\
\text { equilibrium -Turner et al. } \\
1996 \text { (U) and Zachara et } \\
\text { al. } 2002 \text { (Cs); kinetic - } \\
\text { Liu et al. } 2003 \text { (Cs), Liu } \\
\text { et al. } 2004 \text { (U), and } \\
\text { McKinley et al. } 2006 \\
\text { (Sr). Experimental } \\
\text { results are fitted with } \\
\text { various geochemical } \\
\text { models (MINTEQ; } \\
\text { Geochemists Workbench; } \\
\text { GMIN; or FITEQL see } \\
\text { below) to identify suites } \\
\text { of adsorption reactions } \\
\text { (ion exchange or surface } \\
\text { complexation). }\end{array}$ & -- \\
\hline
\end{tabular}




\begin{tabular}{|c|c|c|c|}
\hline Method & Analysis & Document Number & Procedure Title \\
\hline Column experiments & $\begin{array}{l}\text { Sediment ( }<2 \text { mm or }<4 \\
\text { mm) is packed into a } \\
\text { cylindrical plastic, glass, } \\
\text { or stainless steel } \\
\text { column. Electrolyte } \\
\text { with or without a } \\
\text { contaminant tracer is } \\
\text { applied to the column to } \\
\text { study the release (from } \\
\text { contaminated sediment) } \\
\text { or sorption/retardation } \\
\text { (for uncontaminated } \\
\text { sediments) of key } \\
\text { contaminants of } \\
\text { concern. }\end{array}$ & $\begin{array}{l}\text { Qafoku et al. 2005. The } \\
\text { basic experimental data } \\
\text { that is in the form of } \\
\text { chemical concentration as } \\
\text { a function of leaching } \\
\text { volume of fluid, must be } \\
\text { modeled with various } \\
\text { commercial and research } \\
\text { codes to yield useable } \\
\text { information. CXTFIT is } \\
\text { used to fit physical } \\
\text { transport parameters such } \\
\text { as the dispersivity, while } \\
\text { other models are linked } \\
\text { with a solver of the } \\
\text { advective-dispersion } \\
\text { equation to describe 1- } \\
\text { dimensional reactive } \\
\text { transport. The reactive } \\
\text { transport models include } \\
\text { a commercial one (the } \\
\text { Geochemists Workbench) } \\
\text { and others assembled by } \\
\text { the research team } \\
\text { including the Distributed } \\
\text { Rate Model (DRM) and } \\
\text { the Dual Continuum } \\
\text { Model (DCM). These are } \\
\text { described below. }\end{array}$ & -- \\
\hline MINTEQA2 Version 4 & $\begin{array}{l}\text { Commercial software } \\
\text { used to calculate } \\
\text { aqueous speciation, } \\
\text { precipitation/dissolution, } \\
\text { and } \\
\text { adsorption/desorption } \\
\text { equilibria for low to } \\
\text { intermediate-strength } \\
\text { solutions. }\end{array}$ & $\begin{array}{l}\text { Code published by } \\
\text { Allison et al. } 1991 \text { and } \\
1998 \text { linked to a } \\
\text { thermodynamic database } \\
\text { of our own synthesis (see } \\
\text { below). }\end{array}$ & -- \\
\hline Geochemists Workbench & $\begin{array}{l}\text { Commercial software to } \\
\text { calculate geochemical } \\
\text { equilibria, reaction } \\
\text { network modeling, and } \\
\text { reactive transport. }\end{array}$ & $\begin{array}{l}\text { Geochemists Workbench } \\
\text { Release 6. from Craig } \\
\text { Bethke, Hydrogeology } \\
\text { Program, University of } \\
\text { Illinois }\end{array}$ & -- \\
\hline CXTFIT & $\begin{array}{l}\text { Commercial software } \\
\text { for fitting column } \\
\text { effluent data. }\end{array}$ & Toride et al. 1999 & -- \\
\hline
\end{tabular}




\begin{tabular}{|c|c|c|c|}
\hline Method & Analysis & Document Number & Procedure Title \\
\hline FITEQL (V 4.0) & $\begin{array}{l}\text { Commercial software } \\
\text { used to calculate } \\
\text { equilibrium constants } \\
\text { and their statistics for } \\
\text { aqueous, surface and } \\
\text { precipitated phases from } \\
\text { batch experimental data. }\end{array}$ & $\begin{array}{l}\text { Herbelin and Westall, } \\
1999\end{array}$ & -- \\
\hline GMIN & $\begin{array}{l}\text { An equilibrium } \\
\text { geochemical model used } \\
\text { to calculate aqueous } \\
\text { speciation, precipitation/ } \\
\text { dissolution, and } \\
\text { adsorption desorption } \\
\text { equilibria for high ionic } \\
\text { strength solutions. } \\
\text { Maintained by PNNL. }\end{array}$ & Felmy, 1995 & -- \\
\hline Spectral Fitting Software & $\begin{array}{l}\text { Commercial software } \\
\text { used to fit fluorescence } \\
\text { emission spectra on } \\
\text { U(VI) derived from } \\
\text { CLIFS analyses. The } \\
\text { fitting allows } \\
\text { determination of the } \\
\text { precise spectral } \\
\text { wavelengths and } \\
\text { deconvolutes spectral } \\
\text { signatures resulting } \\
\text { from multiple } \\
\text { fundamental species. }\end{array}$ & Beechem et al. 1991 & -- \\
\hline $\begin{array}{l}\text { Phase Identification for } \\
\text { Powder Diffraction } \\
\text { (JADE+, V 5) }\end{array}$ & $\begin{array}{l}\text { Commercial software } \\
\text { used to manipulate } \\
\text { powder diffraction files } \\
\text { are for comparison with } \\
\text { reference spectra in for } \\
\text { mineral identification. }\end{array}$ & $\begin{array}{l}\text { Materials Data Inc., } \\
\text { Livermore, CA; ICDD, } \\
2003\end{array}$ & -- \\
\hline
\end{tabular}




\begin{tabular}{|c|c|c|c|}
\hline Method & Analysis & Document Number & Procedure Title \\
\hline $\begin{array}{l}\text { Reactive Transport } \\
\text { Modeling }\end{array}$ & $\begin{array}{l}\text { The Dual Continuum } \\
\text { Model (DCM) is used to } \\
\text { model the reactive } \\
\text { transport of } \\
\text { contaminants 1- } \\
\text { dimensional laboratory } \\
\text { columns and in } \\
\text { multidimensional field } \\
\text { simulations. The model } \\
\text { is a reaction-based } \\
\text { simulator and requires } \\
\text { significant } \\
\text { parameterization using } \\
\text { batch and column data, } \\
\text { and physical } \\
\text { measurements of } \\
\text { sediment characteristics. } \\
\text { Maintained by LANL. }\end{array}$ & $\begin{array}{l}\text { Lichtner et al. 2000; } \\
\text { Lichtner et al. } 2001\end{array}$ & -- \\
\hline $\begin{array}{l}\text { Empirical Kinetic } \\
\text { Modeling }\end{array}$ & $\begin{array}{l}\text { The distributed rate } \\
\text { model (DRM) is used to } \\
\text { empirically describe } \\
\text { complex kinetic } \\
\text { desorption/dissolution } \\
\text { phenomena in sediment } \\
\text { that is controlled by } \\
\text { chemical kinetics or } \\
\text { diffuse mass transport. } \\
\text { The basic model } \\
\text { describes kinetic } \\
\text { phenomena using a } \\
\text { statistical distribution of } \\
\text { first order rate constants. } \\
\text { Maintained at PNNL. }\end{array}$ & Culver et al. 1997 & -- \\
\hline $\begin{array}{l}\text { Surface Complexation } \\
\text { Model }\end{array}$ & $\begin{array}{l}\text { The surface } \\
\text { complexation model } \\
\text { (SCM) is used to } \\
\text { describe the surface } \\
\text { chemical reactions of } \\
\mathrm{U}(\mathrm{VI}) \text { that are } \\
\text { responsible for its } \\
\text { adsorption to vadose } \\
\text { zone and aquifer } \\
\text { sediments. Maintained } \\
\text { by USGS. }\end{array}$ & Davis et al. 2004 & -- \\
\hline
\end{tabular}




\begin{tabular}{|c|c|c|c|}
\hline Method & Analysis & Document Number & Procedure Title \\
\hline $\begin{array}{l}\text { Thermodynamic } \\
\text { Database }\end{array}$ & $\begin{array}{l}\text { A large thermodynamic } \\
\text { database is maintained } \\
\text { and constantly updated } \\
\text { based on literature } \\
\text { advances. The database } \\
\text { describes stability } \\
\text { constants for aqueous } \\
\text { complexes and } \\
\text { solubility products for } \\
\text { precipitated phases } \\
\text { relevant to S\&T } \\
\text { research and issues. } \\
\text { This database is used in } \\
\text { almost every S\&T } \\
\text { geochemical study. } \\
\text { There are many } \\
\text { hundreds of entries in } \\
\text { the database for a } \\
\text { variety of contaminants } \\
\text { that is used in } \\
\text { MINTEQA@; } \\
\text { Geochemists } \\
\text { Workbench, and all of } \\
\text { the reactive transport } \\
\text { codes. Maintained at } \\
\text { PNNL. }\end{array}$ & $\begin{array}{l}\text { The database relies on the } \\
\text { following and many other } \\
\text { sources: Grenthe et al. } \\
1992 \text { (U); Guillaumount } \\
\text { et al. } 2003 \text { (U); Rard, } \\
1999 \text { (Tc) }\end{array}$ & -- \\
\hline
\end{tabular}

\section{B.1 References}

Allison JD, DS Brown, and KJ Novo-Gradac. 1991. MINTEQA2/PRODEFA2, A Geochemical Assessment Model for Environmental Systems: Version 3.0 User's Manual. U.S. Environmental Protection Agency, Washington, D.C.

Allison JD, DS Brown, and KJ Novo-Gradac. 1998. MINTEQA2/PRODEFA2, A Geochemical Assessment Model for Environmental Systems: User Manual Supplement for Version 4.0. U.S. Environmental Protection Agency, Washington, D.C.

Beechem JM, E Gratton, and WW Mantulin. 1991. Globals Unlimited. UIUC Publication.

Catalano JG, JP McKinley, JM Zachara, SC Smith, and GE Brown, Jr. 2006. "Changes in Uranium Speciation Through a Depth Sequence of Contaminated Hanford Sediments.” Environmental Science \& Technology (Submitted). 
Catalano JG, SM Heald, JM Zachara, and GE Brown, Jr. 2004. "Spectroscopic and Diffraction Study of Uranium Speciation in Contaminated Vadose Zone Sediments from the Hanford Site, Washington State.” Environ. Sci. Technol. 38:2822-2828.

Culver TB, SP Hallisey, D Sahoo, JJ Deitsch, and JA Smith. 1997. "Modeling the Desorption of Organic Contaminants from Long-Term Contaminated Soil Using Distributed Mass Transfer Rates.” Environ. Sci. Technol. 31:1581-1588.

Davis JA, DE Meece, M Kohler, and GP Curtis. 2004. “Approaches to Surface Complexation Modeling of Uranium(VI) Adsorption on Aquifer Sediments.” Geochim. Cosmochim. Acta 68:3621-3641.

Felmy AR. 1995. “GMIN. A Computerized Chemical Equilibrium Program Using a Constrained Minimization of the Gibbs Free Energy: Summary Report.” In Chemical Equilibrium and Reaction Models (eds. RH Loeppert, AP Schwab, and S Goldberg) pp. 377-407, Soil Science Society of America.

Fredrickson JK, JM Zachara, DW Kennedy, RK Kukkadapu, JP McKinley, SM Heald, C Liu, and AE Plymale. 2004. "Reduction of $\mathrm{TcO}^{4-}$ by Sediment-Associated Biogenic Fe(II)." Geochim. Cosmochim. Acta 68(15):3171-3187.

Grenthe I, J Fuger, RJM Konings, RJ Lemire, AB Muller, C Nguyen-Trung, and H Wanner. 1992. Chemical Thermodynamics of Uranium. North-Holland, Amsterdam.

Guillaumount R, T Fanghanet, V Neck, J Fuger, DA Palmer, I Grenthe, and MH Rand. 2003. Update on the Chemical Thermodynamics of Uranium, Neptunium, Plutonium, Americium, and Technetium. Elsevier.

Hammersley AP. 1997. FIT2D: An Introduction and Overview. Internal Report ESRF97HA02T; European Synchrotron Radiation Facility, Grenoble, France.

Herbelin A and J Westall. 1999. FITEQL: A Computer Program for Determination of Chemical Equilibrium Constants from Experimental Data, Version 4.0. Report 99-01. Oregon State University, Corvallis, Oregon.

ICDD. 2003. JCPDS Powder Diffraction Files, PDF. International Centre for Diffraction Data (ICDD), Newtown, Square, Pennsylvania.

Ilton ES, C Liu, W Yantasee, Z Wang, D Moore, and JM Zachara. 2005. “The Effect of Carbonate on the Dissolution of Synthetic Na-Boltwoodite.” Geochimica et Cosmochimica Acta (Submitted).

Kukkadapu RK, JM Zachara, JK Fredrickson, and DW Kennedy. 2004. "Biotransformation of Two-Line Silica-Ferrihydrite by a Dissimilatory Fe(III)-Reducing Bacterium: Formation of Carbonate Green Rust in the Presence of Phosphate.” Geochim. Cosmochim. Acta 68(13):2799-2814.

Lichtner PC. 2001. FLOTRAN: User's Manual. Report No. LA-UR-02-2349, Los Alamos National Laboratory, Los Alamos, New Mexico.

Lichtner PC. 2000. "Critique of Dual Continuum Formulations of Multicomponent Reactive Transport in Fractured Porous Media, Dynamics of Fluids in Fractured Rock.” Geophys. Monograph 122:281-298. 
Liu C, JM Zachara, W Yantasee, PD Majors, and JP McKinley. 2006. “Microscopic Reactive Diffusion of Uranium in the Contaminated Sediments at Hanford, USA: Characterization and Modeling." Water Resources Research (Submitted).

Liu C, JM Zachara, O Qafoku, JP McKinley, SM Heald, and Z Wang. 2004. "Dissolution of Uranyl Microprecipitates in Subsurface Sediments at Hanford Site, USA.” Geochim. Cosmochim. Acta 68(22):4519-4537.

Liu C, JM Zachara, SC Smith, JP McKinley, and CC Ainsworth. 2003. "Desorption Kinetics of Radiocesium from Subsurface Sediments at Hanford Site, USA.” Geochim. Cosmochim. Acta 67(16):2893-2912.

McKinley JP, JM Zachara, SC Smith, and C Liu. 2006. “Cation Exchange Reactions Controlling Desorption of ${ }^{90} \mathrm{Sr}^{2+}$ from Coarse-Grained Contaminated Sediments from the Hanford Formation, Washington.” Geochimica et Cosmochimica Acta (Submitted).

McKinley JP, JM Zachara, C Liu, and SC Heald. 2005. "Precipitation of Waste Uranium as a Uranyl Silicate in Microfractures.” Geochimica et Cosmochimica Acta (In press).

McKinley JP, RJ Serne, JM Zachara, CJ Zeissler, and RM Lindstrom. 2001. “The Distribution and Retention of ${ }^{137}$ Cs in Sediments at the Hanford Site, Washington.” Environ. Sci. Technol. 35:3433-3441.

Newville M. 2001a. “IFEFFIT: Interactive XAFS Analysis and FEFF Fitting.” J. Synch. Rad. 8:322-324.

Newville M. 2001b. “EXAFS Analysis Using FEFF and FEFFIT.” J. Synch. Rad. 8:96-100.

Qafoku NP, JM Zachara, C Liu, PL Gassman, OS Qafoku, and SC Smith. 2005. “Kinetic Desorption and Sorption of U(VI) During Reactive Transport in a Contaminated Hanford Sediment.” Environ. Sci. Technol. 39:3157-3165.

Rard JA, MH Rand, G Anderegg, and H Wanner. 1991. Chemical Thermodynamics of Technetium, Chapter 3; (MCA Sandino and E Osthols, eds.), Elsevier, The Netherlands, Amsterdam, pp. 544.

Toride N, FJ Leij, and MT van Genuchten. 1999. The CXTFIT Code for Estimating Transport Parameters from Laboratory or Field Tracer Experiments. U.S. Salinity Laboratory.

Turner GD, JM Zachara, JP McKinley, and SC Smith. 1996. "Surface-Charge Properties and $\mathrm{UO}_{2}{ }^{2+}$ Adsorption of a Subsurface Smectite.” Geochim. Cosmochim. Acta 60:3399-3414.

Wang Z, JM Zachara, PL Gassman, O Qafoku, and J Catalano. 2005a. "Fluorescence Spectroscopy of U(VI)-Silicates and U(VI)-Contaminated Hanford Sediment.” Geochim. Cosmochim. Acta 69(6):1391-1403.

Wang Z, JM Zachara, JP McKinley, SC Smith, and SM Heald. 2005b. “Cryogenic Laser Induced U(VI) Fluorescence Studies of a U(VI) Substituted Natural Calcite: Implications to U(VI) Speciation in Contaminated Hanford Sediments.” Environ. Sci. Technol. 39:2651-2659. 
Wang Z, JM Zachara, W Yantasee, PL Gassman, C Liu, and AG Joly. 2004. “Cryogenic Laser Induced Fluorescence Characterization of U(VI) in Hanford Vadose Zone Pore Waters.” Environ. Sci. Technol. 38(21):5591-5597.

Webb SM. 2005. “SIXPack: A Graphical User Interface for XAS Analysis Using IFEFFIT.” Phys. Scr. T115, 1011-1014.

Zachara JM, SC Smith, C Liu, JP McKinley, RJ Serne, and PL Gassman. 2002. "Sorption of Cs+ to Micaceous Subsurface Sediments from the Hanford Site, USA.” Geochim. Cosmochim. Acta 66:193-211.

Zeissler CJ, RM Lindstrom, and JP McKinley. 2001. "Radioactive Particle Analysis by Digital Autoradiography.” J. Radioanal. Nuclear Chem. 248(2):407-412. 



\section{Distribution}

No. of

Copies

ONSITE

11 Pacific Northwest National Laboratory
C. A. Carlson
K9-78
D. D. Dauble
K6-83
N. J. Fix
M. D. Freshley
R. R. Labarge
W. R. Martin
D. F. Mahon
T. L. Stewart
M. J. Truex
Hanford Technical Library (2)

No. of

Copies

\section{OFFSITE}

All EM-20 Roadmap Project Participants (to be provided as a PDF). 